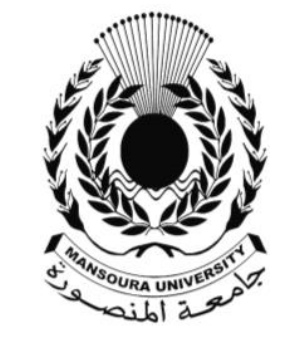

جامعة المنصـورة الماني

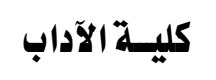

\title{
قيم السيادة في وصايا خلفاء بني العباس (وصايا الخليفة العباسي أبي جعفر المنصور لابنه المهدي نموذجا) دراسة في الرؤية.
}

\author{
إعـــ/د \\ الدكتورة/ فاطمة السراحنه \\ كلية الآداب - الجامعة الهاشمية
}

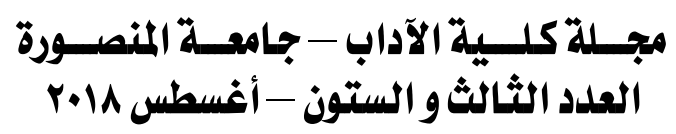




\section{قيم السيادة في وصايا خلفاء بـني العباسر

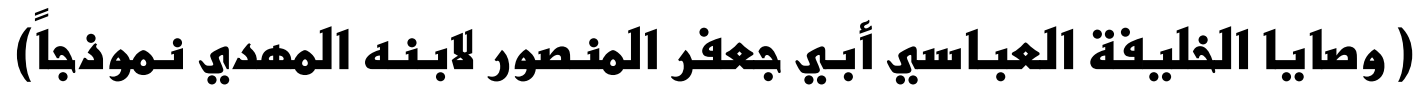 \\ دراسة في الرؤية.}

\section{د/ فاطمة السراحنه}

ملخص البعث:

تنتظم هذه الدراسة في باب إظهار اهتمام خلفاء بني العباس بأبنائهم منذ باكورة الدولة العباسية بالعناية وتذكية سلوكهم والارتقاء بهم:

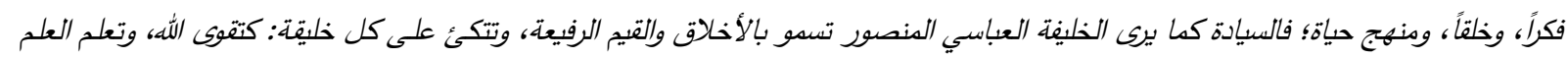

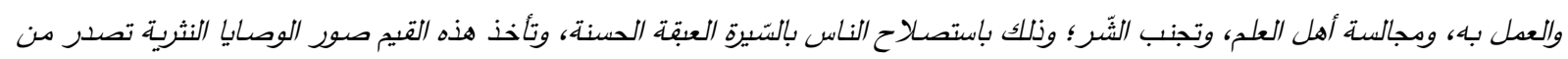

الآباء بعدما اعتركوا الحياة وجابهوا عويصها.

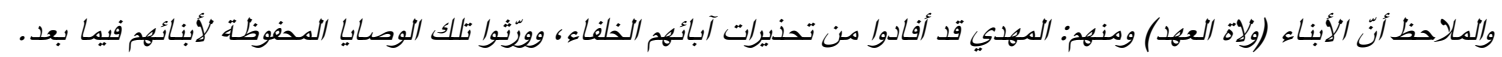

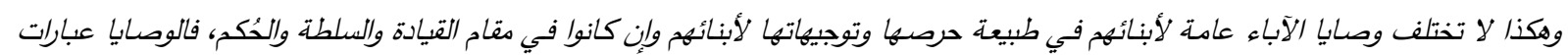

نفيسة تكتب بمداد من ذهب.

Abstract

This study shows the care of the successors of bani Al Abass to their sons since the beginning of establishment their country by paying attention to their behavior and upgrading them thought, creation, and a way of life; in that days the power was superior to ethics and high values. These values took the pictures of the proverbs from parents after they have come to life and confronted them. Sons of the Covenant reported the warnings of their forefathers, who inherited the commandments that were kept for their sons. Thus, the commandments of the fathers in general do not differ for their sons in the nature of their care and guidance, although they are in the place of leadership, power and governance.

خصوصـية؛؛ فهـي تصــدر مسن الخليفـة العباسـي الإقدمــة : وتقدم لابنـه بغيـة ديمومتـه في الملك واسـتمراره، ارتبطت السيادة بالهيمنـة والسلطة والسطوة، كمـا وتحرص على الرعية، وتحمل عاطفة أبوة صادقة، كما أنها تصدر من خليفة اليوم الذي يوشك على الارتحال أو اقتربت ساعة موته إلى خليفة الغد؛ للمحافظة على ميراث الخلافة الذي يتهافت عليه الطامعون، وقد ارتكزت على قيم السيادة وآدابها، والسـيادة لفظـة تحمـل في طياتها مـا يـدل على صـاحب الجـاه والمكانـة والرفعـة. وقد عنيت مثل في هذه الوصايا بمضامين رفيعة، كما بنيت بناءً فنياً متمايزاً. تسـى هذه الدراسـة إلى الاهتمـام بتلك الوصـايا الصـادرة مـن الخليفـة المنصـور إلى ابنـه المهدي

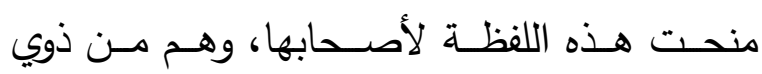
المقامات السامية، حريـة في التصرف كبيرة، فمن يخضــعون لهـم مـن الرعيـة يلتزمــون بطــاعتهم والرضوخ لهم، والانقياد لأوامرهم.

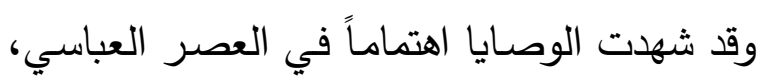
وأهمها تلك الوصسايا التي صدرت من الخلفاء إلى أبنائهم وبخاصـة الخليفـة العباسـي المنصسور الذي وجههـا لابنــه المهدي، موضـوع الدراسـة، وأهميـة هذه الوصـايا تتبع في تمثيلهـا لمظـاهر العنايـة بوسائل الارتقاء بالبشرية، وبناء الحضارة ، وتجمع بين الدين والدنيا. وتحمل وصسايا الخليفة العباسي بـي 
إلا إذا وجـــ الثــص أو الجماعـة التـي تمـارس

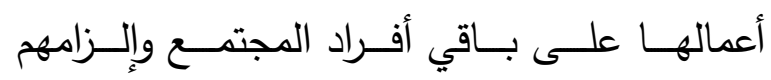
بالانصياع لأمرهم. وهكذا فِإنّ السيادة اصطلاحاً كلمـة لاتينـة تعبر

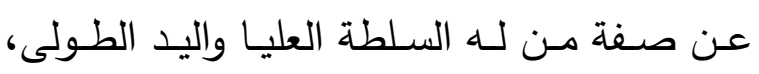

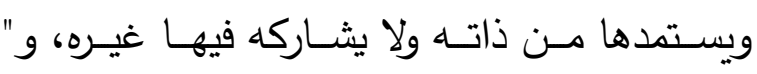

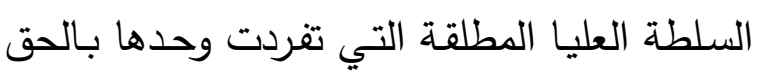

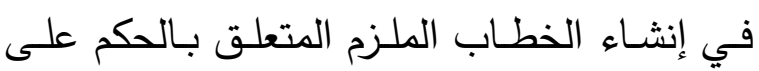

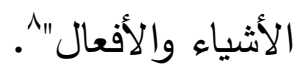

\section{ثانياً : مفهوم الوصية :}

اشتقت الوصية من " وصي" ولغة تعني الوصل" معلي

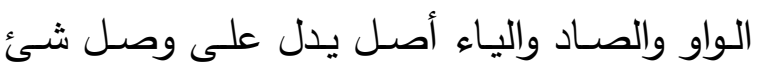
بثئ، ووصيت الثئ وصلته" ، ، وأكد المعنى نفسه ولى وصل

$$
\text { الزمخشري:" وصى الثئ: وصله" 'أ. }
$$

أما الوصية في لسان العرب فتعني العهد، وأوصى وصى لوصى

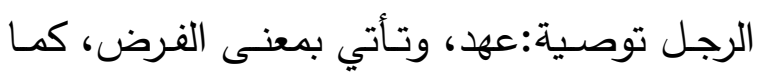

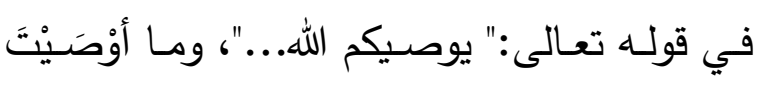

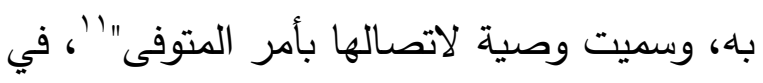
حين نجد الوصية في المعجم الوسيط:" قول فيه

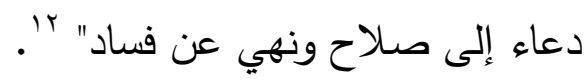

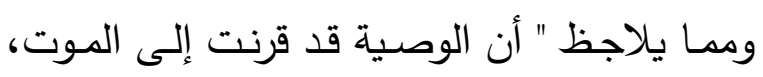

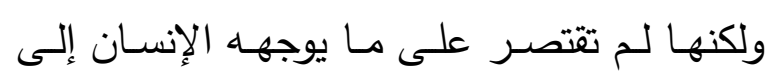
خلفائه في هذا المقام، بل توسع في الاستعمال في كل قول عزيز يحرص الموصي على توجيهه إلى هلى

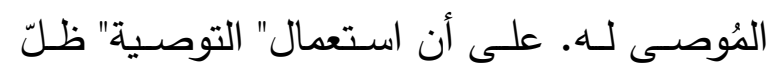

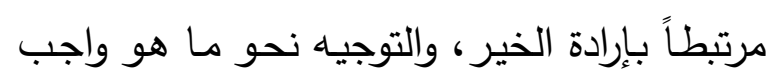

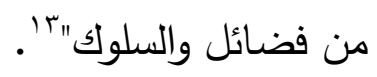

وهي ضـرب من الخطابة تقتصر على المقربين

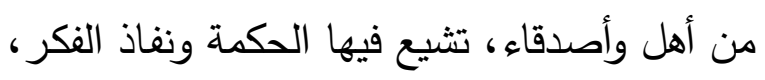

من كتب مختلفة، ومعرفة القضـايا التي شغلته.

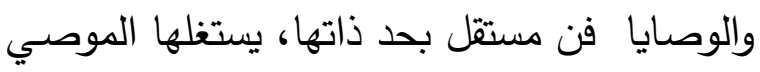
لفرض فكرة، ضمن سياق فني له صفاته.

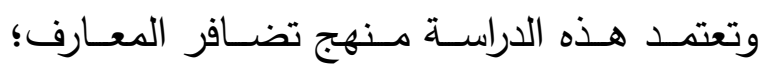

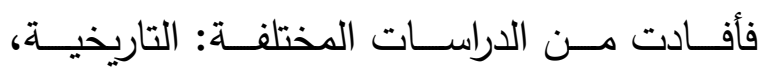

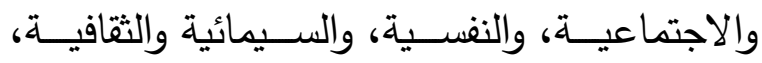

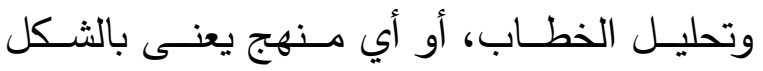

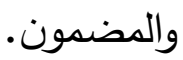

\section{أولاً: مفهوم السيادة}

السيادة لغـة من سود، يُقال : فـلان سيّّ قومـه إذا

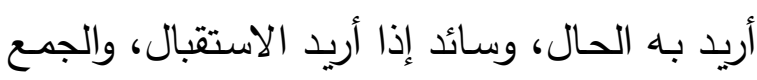
سـادة. '. وذهـب آخـرون في معنى السّيديد غير

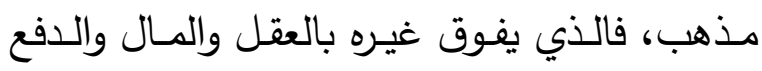

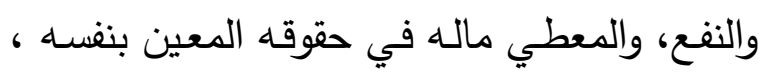

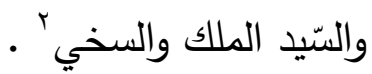
والمّيديد (كذلك) لفظـة تطلق على الكرّب والمالكـ

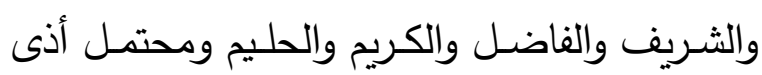

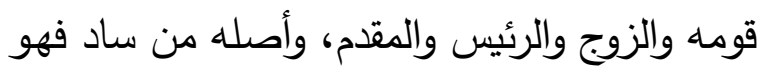

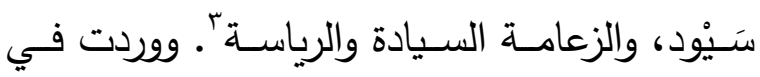

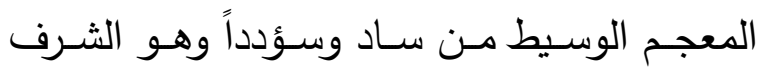

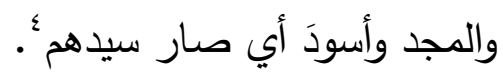

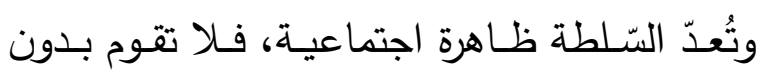
جماعة، ولاتنهض الجماعة إلا إذا وجدت سلطة

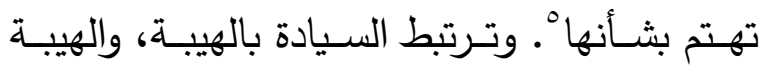
تتحقق بالحب والخوف" فالثعب قد يهاب حاكمهـ

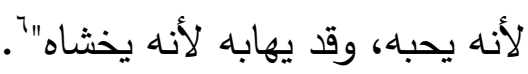
وتقترن السلطة السياسية ووجود الدول بالسيادة وهي متصلة بالمجتمع، وهكذا يمثل الفرد حجر

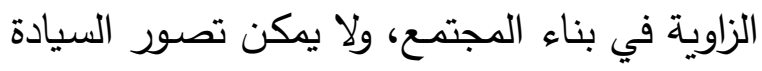


الأحيـاء:" للأحيـاء وهـي أدب، وأمـر بـالمعروف ونهي عن منكر، وتحذير من زلل، وتبصرة بعمل صالح، ووصية الأموات للأحياء عند الموت بحق ونق

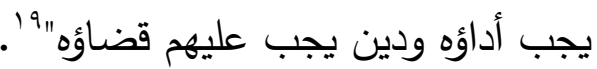
والوصايا تسجيل صادق على طبيعة حياة العرب البسيطة، وتسعى لمراعاة قيمه الأخلاقية، كما تعنى بالخصال الحميدة ومكارم الأخلاق، فقد كان

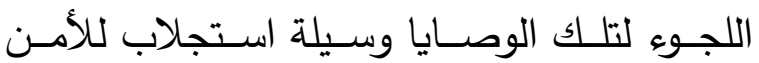

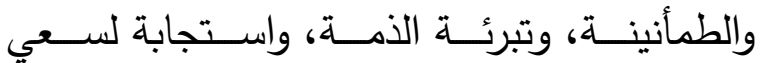
الموصسي للمصلحة، وقد حفظ التاريخ ثلـة مـن

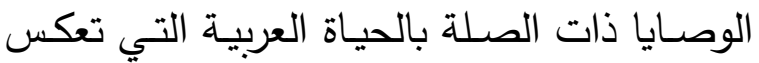
تطور القيم والمواقف الصـادقة لأنماط العلاقات

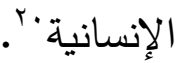

وقــــــــت الوصــايا حاجــات الإنســان

العربي، فهي حاجة من حاجات الحياة الاجتماعية والسياسـية التي اسـتدعتها طبيعـة حيـاتهم التي التي

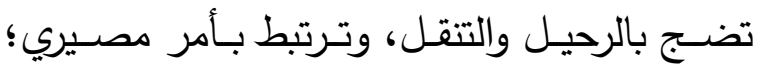
كالزواج، كمـا كانت تتصل بمواضيع مهــة في لحظتها، فغالباً ما تكون من شخص أسنّ، وأشرف كانت على الموت، وهي امتداد للفطرة السوية" ولو تتبعنا

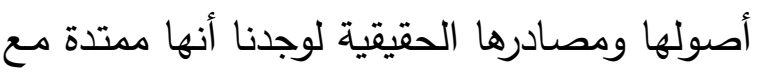

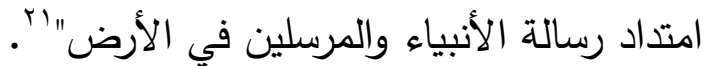

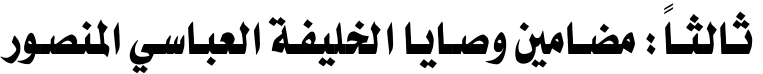

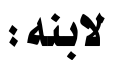
ومن النصوص التي عنيت بقيم السيادة، وتتصل

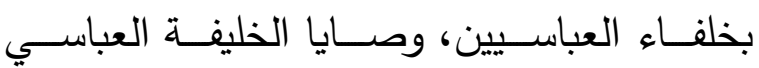

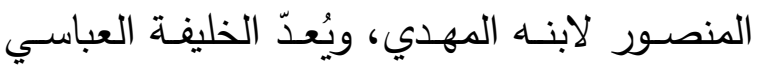
المنصور المؤسس الحقيقي للدولة العباسية؛ فقد

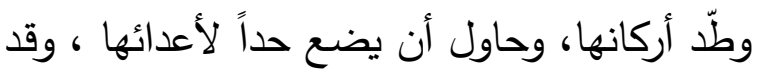

وتمتاز برقتها وتناسب جملهاء'، والفرق بينهما أن الخطبة يقصد بها جمع من الناس ، وحثهم على أمر من الأمور العامـة التي تتعلق بثؤون الدنيا

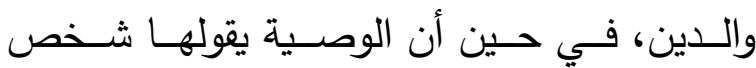

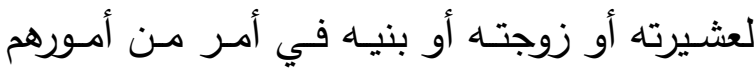
الخاصة عند إحساسه بدنو الأجل أو الرحيل إلى آلى لئه مكان آخر '. وتعرف الوصايا أدبياً، أيضاً، بكلام مستخلص من تجارب الحياة" يقوله من عُرف بين الناس بحكمته الدقيقة، ونظرتـه الثاقبة، وتقديره السـيد للأمهور التي مارسها ووقف على كنهها وأسرارها، ليهتدي

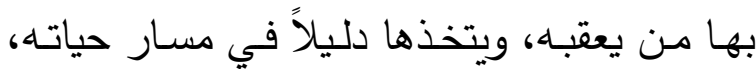

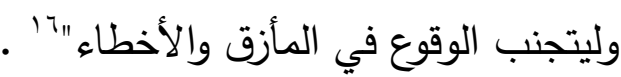
وهكذا فإن الوصية الأدبية:" نوع من أنواع الأدب

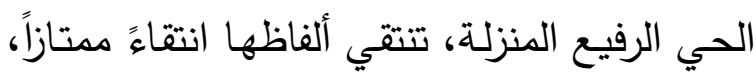
يطلقها مجرب حياة ومختبر دنيا، فيشرع فيها نهجاً قويماً وسلوكاً تنظيمياً لإنسان عزيز عليه أو مهح لديه، يبصره ما ينبغي عليه أن يفعله فيما يستقبل

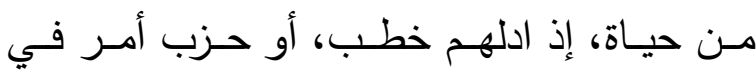

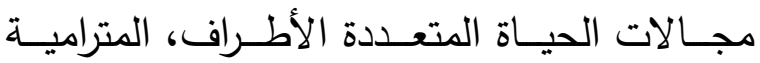

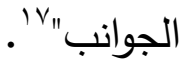
والوصايا تختلف من حيث الموصى إليه وعلاقته بالموصي، فهي قسمان: خاصة وعامة، والخاصـة منها: موجهة إلى شخص معين، وتتضمن توجيه

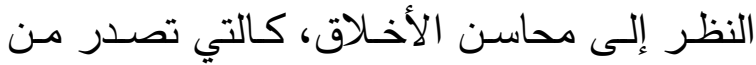

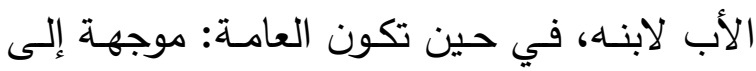
فئة من الناس أو إلى الناس بوجه عام، وتكون لعاده: موجنه

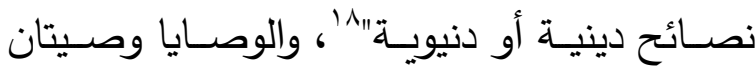

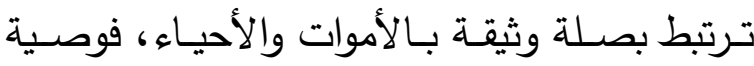


بالإســلام، ومـرجعهم القرآن والحديث النبوي ممـا يبرز قوة الإيمان وهيبتهـ ممزوجـة بأبهـة السلطان

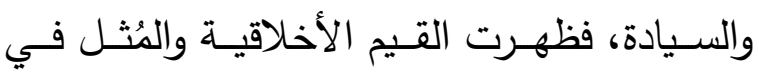
أفعالهم وأقوالهم، وهكذا فقد ساست الدولة العباسية

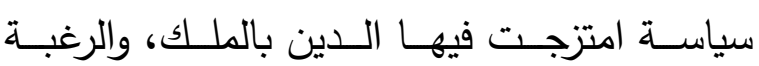
بالرهبة" إلا أنها كانت دولة كثيرة المحاسن، جمة لهـ المكـارم، أسـواق العلـوم قائمــة... وبضــائع الآداب نافقة، وشعائر الدين معظمة" إذن، فقد نهلت وصايا الخليفة العباسي المنصور من هذا المعين الثرّ ذي الطـابع الإسـلامي؛ فهو يؤكد أهمية التقوى وكأنها منطلق الخلافة والسيادة، وينبع من ذلك الإحساس الدائم برقابـة الله، فيأوي إلىى ركن شـديد وهـو الخضــوع لله، الــي يعنـي

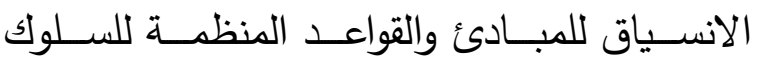
البشـري، التـي يحددها الـدين القويم؛ كمـا يقترن الـدين بـالأخلاق السـامية، ويتمثل في أسـاليب التعامل، ويتحقق بذلك تماسك المجتمع والسلطة، يقول:" إنّ أميرَ المؤمنين يُوصـيك بتقوى اللهِ في البلادِ، والعملِ بطاعتِه في العبادِ" بـ ، ويقول في مـوطن آخر :" يـا أبـا عبدالله، اتقِي اللهِ فيمـا أعهــُ إليكََ من أمورِ المسلمين بعدي، يجعل لك فيما

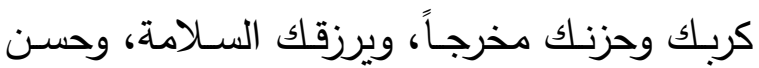

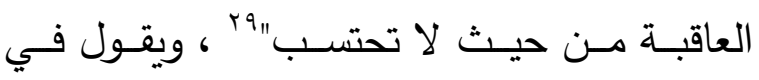

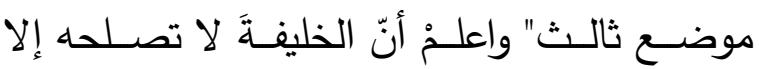

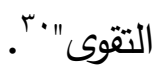
وهكا فإنّ الخليفة المنصور تنبّه إلى أهمية الدين في توطيد أركـان الدولـة وتثبيتهـا، فهو المحرك لإعطـاء السـلطة طاقـة روحيـة، وكسـب احتـرام

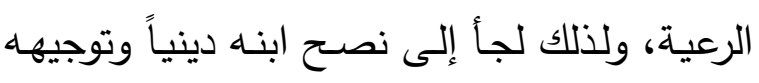

خلّدت كتب التراث وصـايا ثمينـة قدمها لوريــث عرشه المهدي، يحذره ويحرص عليه ويدعوه لتعهد شـؤون الحكم وتدبيرها، كمـا تعنى تلك الوصـايا بأمور الرعية.

ويُعـرف الخليفــة العباســي الثـاني أبـو جعفــر المنصـور بأنـهـه مـن دهـاة العـرب: سـديد الـرأي ؛

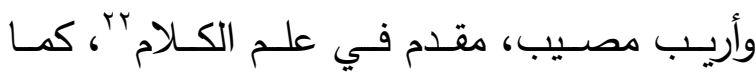
وصـف أنــه مـن أحسـن النـاس خلقـاً، وأشــدهم احتمـالاًّمَ، و" كـان المنصــور فـي أول النهـار يتصـدى للأكــر بـالمعروف، والنهـي عـن المنكـر

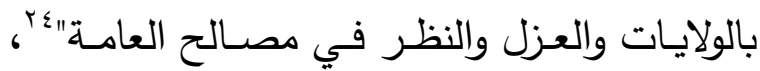
وقد عني بوعاظ عصره وعلمائه وانعكس هذا عليه

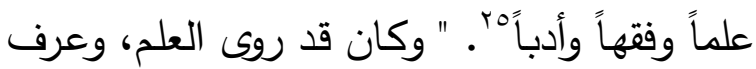
الحـلال والحـرام، وسـاس هـو وبنـوه ملكهم سياسـة

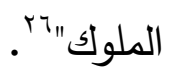
وقد انتهج الخليفة أبو جعفر المنصور نهجاً في مضـامين وصـاياه لابنـه، فهـو يجمسع بـين الواقـع بظروفه المختلفة والمثالية؛ فالإحسان والعمل في الحياة الدنيا ينعكس على الآخرة فوزاً ورضـا ، وقد ظهرت أهميـة وصـايا الخليفـة العباسـي المنصـور في سعيه مـن ورائها إلى نقل خبرتـه في مجـال السلطة وعلاقته الإنسانية؛ فاجتمعت فيها الحكمة ولهـ وتتظـيم الحيـاة السياسـية وتـدبير شـؤونها، كمـا أسـهمت في إبراز البعد النفسي والعـاطفي. ولعـل من أكثر المضامين ظهوراً:

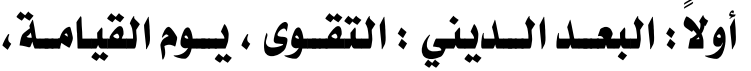

العدل

أحاط الخلفاء العباسيون أنفسهم بهالة من الدين، فكـان الــدين القيمــة الثقافيــة العليــا، وتمســكوا 
لمـا فيـه مـن وسـائل الحمايـة والوقايـة، فـإن سـلك سـلوك النبي القويم ، فسـيحقق بقيـة مـا بقى مـن مكارم الأخـلاق، ويفرض تتبع النبي قدراً عظيماً

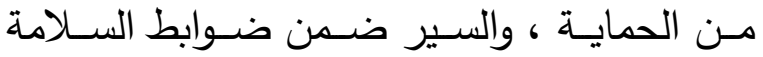
وتحقيق العدل، وهكذا فإن من يستحق السيادة من يتمسك بالأخلاق، يقول: "احفظ يا بني حمداً صلى الله عليه وسلم في أمته، يحفظ الله عليك أمورك، وإيـالك والـدم الحـرام، فإنــه حُوبُّ عندـ الله عظـيم، وعارٌ في الدنيا لازم مقيم، والزم الحلال، فإن فيه ثوابك في الآجـل، وصـلاحك في العاجـل، وأقم

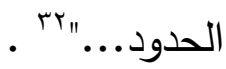

وتتكثــف بــالقراءة الداخليــة أنســاق متضــــادة متصـارعة توضـح موقف الإنسـان منذ الأزل مـن إشكالية الوجود، فالوجود الإنسـاني يتصدس ع بعيداً

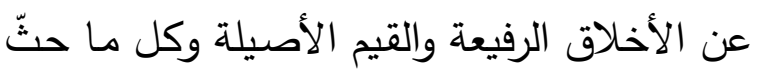
عليه الدين. والخليفـة يُلحِّ على تطبيق الحدود؛ للأكـان الذي تـوفره للدولـة، ومـا يكمـن وراءهــا مـن مصــالح عظيمة، وهي ترتبط بما حرم الله ونهاهـا والعقوبـة التـي تحـل بمنتهكهـا؛ فـاله عزوجـل واضــع هـذهـ القـوانين لمعرفتـهـ بصـلاحها للمجتمـع وإن خفيــ عليهم، وفيها تنفيذ لأوامـر الله، والخليفـة لابـدّ ألا يتجـاوز شـرع الله؛ فهو حبـل الله المتين وعروتـهـ الـوثقى، ومـن هنـا فقد عـاب على أعداء الدولــة ارتكابهم للشرور ، فإذا كانت مهمة الخليفة العظمى الأمـر بـالمعروف والنهـي عـن المنكر ، كـان مـن الطبيعي أن يحثّ الخليفة ابنه على أن يضرب بيد مـن حديـد على يــــ الخـارجين على الدولـة مـن المـارقين والملحدين؛ لأنهم يفسدون في الأرض،
إلى إقامة الشعائر، والتحذير من ارتكاب الذنوب؛ فالوصايا تحرص على جملة من القيم، وهي أشبه بدستور ومنهج متكامل شمل جوانب من شخصية الحـاكم القيـادي الذي يلتقت إلى دقائق الأمـور ، فالتقوى، وتطبيقها ووضعها نصب عيني الموصي بشكل دائم من أهم ما شددت عليه ، والتذكير بما سـيؤؤل إليـــ الخليفــة إن تجبّر ووقـع في الـوزر والإثم. فـالمظلوم سـيقتصّ مـن الظـالمين، ولـذلك قأصــحاب السـيادة والسـلطان أدعى أن يتمسـكوا بـالحق وبالهـدى؛ لأنّ الرعيـة ســــاكي أعمـال الخليفة وعماله وهنا يكمن الخطر ، يقول:

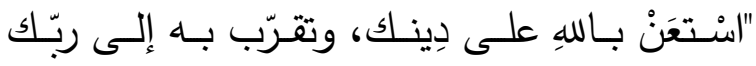

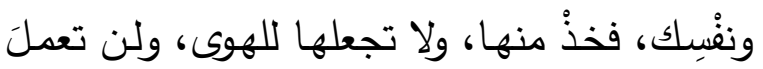

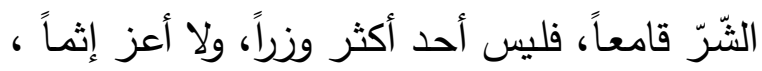

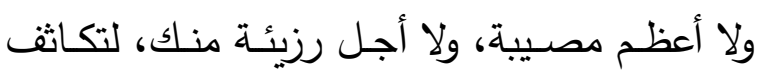

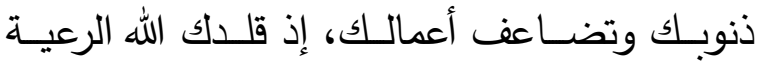
تحكم فيها بمثل الذّرّة، فَيَتْتصـون منك أجْمعون، وتُكافي على أفعالِ وُلاتك الظالمين" "T .

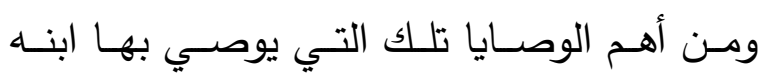
المهـدي ، ويسـند لـه الحكم، ويطلـب لـه الســع والطاعة ممن يحيطون بـه من عشيرته المقربين، وقد بدأ وصيته بالتذكير بعواقب الخروج على أمر الله وعصـيانه، فحــره مـن الحسـرة والندامسة يـوم القيامـة، ومـا سـيؤول إليـه مـن عقـاب إن تتابعــ عليه الذنوب، وذكّر بالنبي تحمه وما أوصسى بـه من الالتزام بأمر الله واجتنـاب نواهيـه، والحفـاظ على بـى الطريق القويم دين التوحيد. إن الخليفـة في رحلـة الخلافـة استقامت لـه الأمسور بفضـل تتبعـه لخطـا النبي عليه السلام في منهج حياته وحسن خُلقه؛ 
للمـال حتى لا ينفقهـ في غير جهته، ممـا جعل

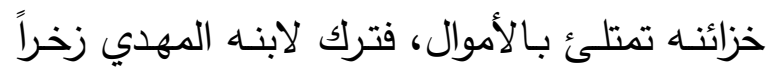

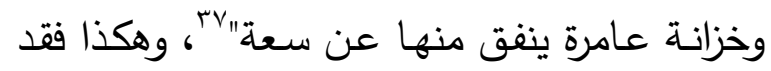
عرف المنصور بأنه رجل لم " يكن له في اللهو

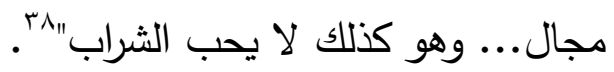

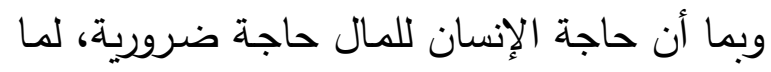
يحققه من هدوء بال وسعادة وطمأنينة واستقرار

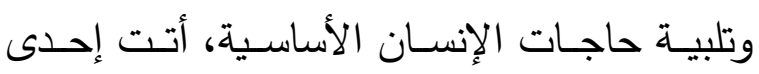

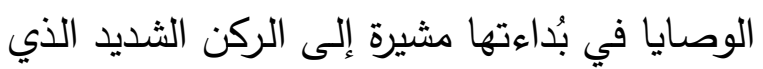

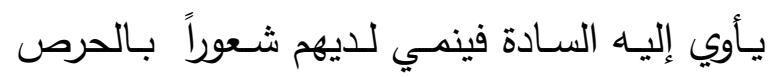

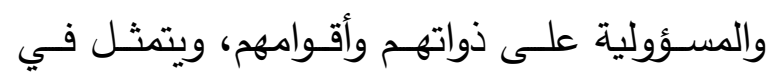

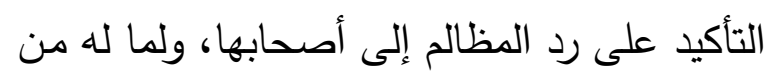
دور في منحح الهيبـة والقدر والحمد عند العامـة. يقول:" يا بني إني قد أفردت كل شئ أخذته من الناس على وجه الجناية والمصادرة، وكتبت عليه أسماء أصحابه، فإذا وليت أنت فأعده على أربابه

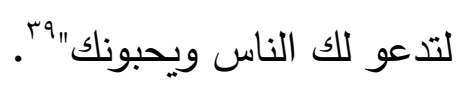

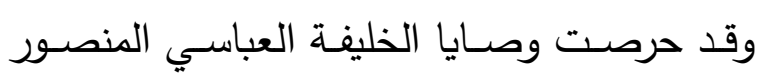
لابنــهـ المهدي علـى بيـان قيمـة المـال، فسـلطان

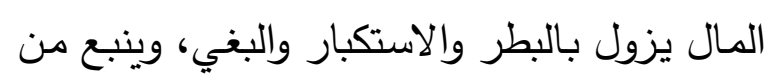

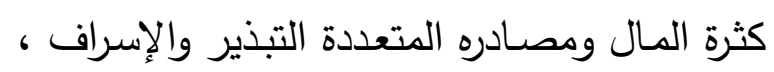
ويتأتى البطر من عدم شكر النعمـة، وإنفاق مـا

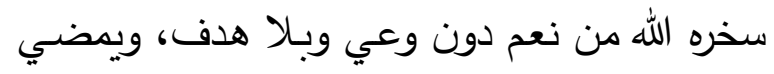

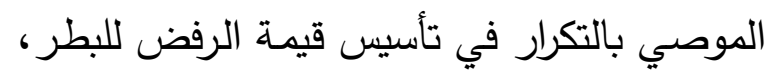
ويبين أثره السلبي على النسق الجماعي.

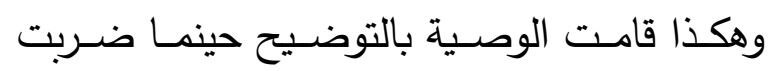

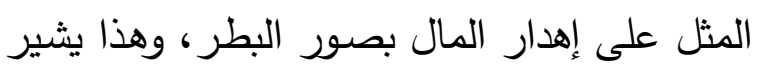

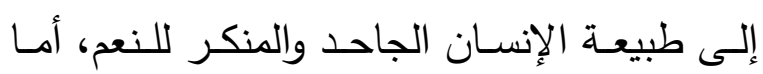

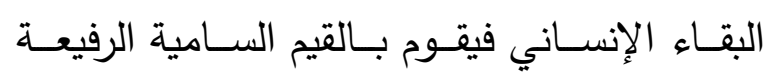

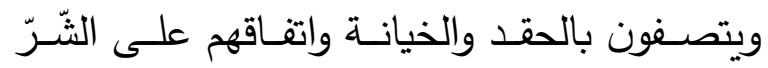
والأذى، وواجب الخليفـة الذود عن الإسـلام مـن مثل هذه الآفات، ويسفه آراء هؤلاء وعقائدهم،

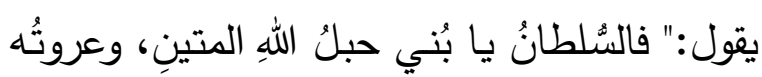

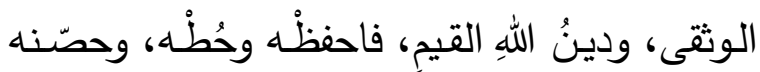
وذب عنـه، وأوقع بالملحدين فيه، وأقــع المـارقين منـه، واقتل الخارجين عنه بالعقاب لهم والمثلات

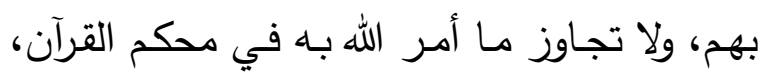

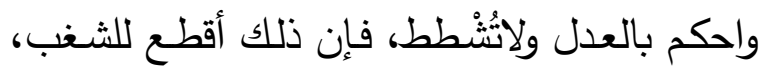

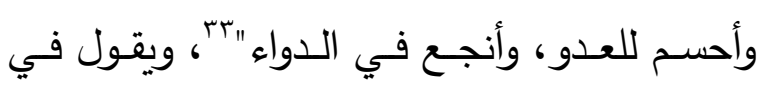

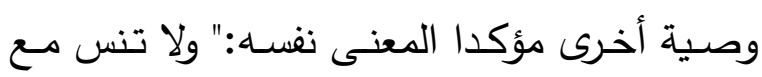
نصيبك من الدنيا نصيبك من رحمة الله"

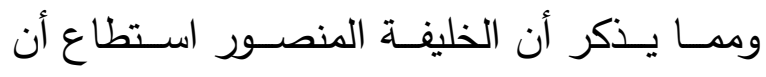
يقضي على معظم الحركات التي تمثل الوثنيـة التي قامت في عصـره من مثل: حركـة سنتباذ

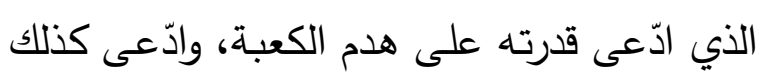

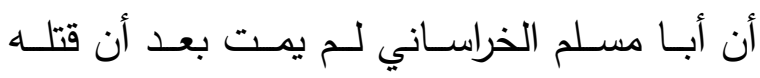

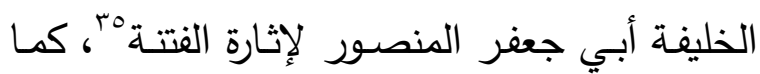

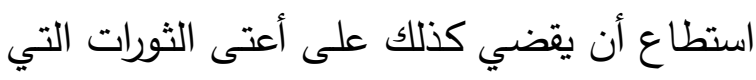

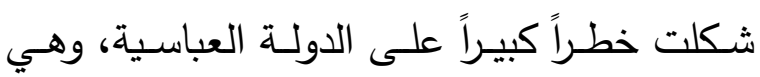

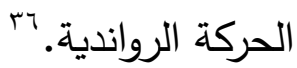
ثانياً : السيادة والمال : أولاً : المـال الــــوة إلى الحفــاظ علـى النعمـة ورد

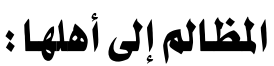

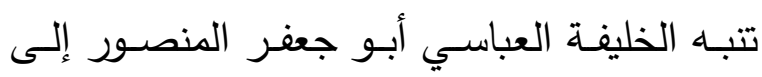

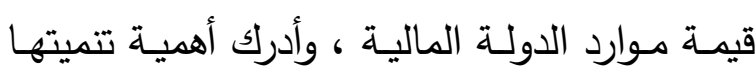

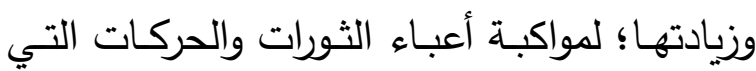
واجهتها الدولة، فقد" عُرف المنصور بحسن تدبيره 
فطالمـا بيـت المـال عـامر بالمـال يبقـى الخليفـة

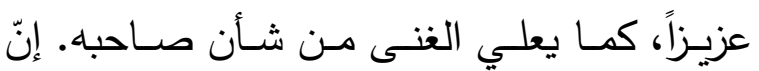

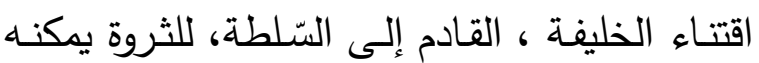
من تحقيـق غاياته، فالسّـيادة وعزهـا يـدوم بالمـال والذكاء في توزيعـه، والخليفـة القـادم مسـخر لهـا الأمر.

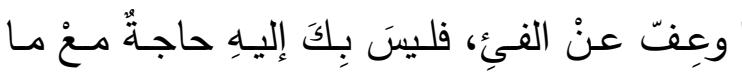

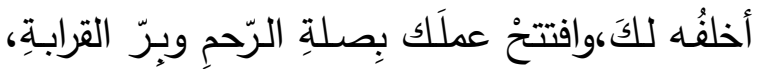

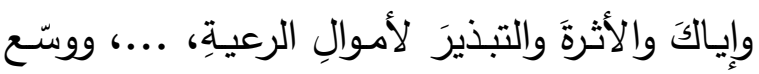

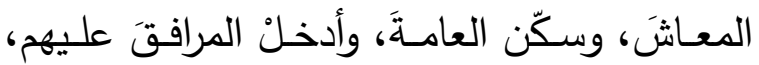
واصـرفت المكـارِة عـنهم، وأعــْ الأمـوالَ واخزنْهــا،

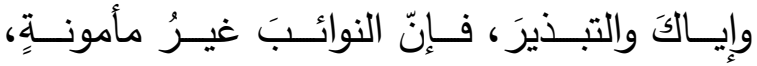
والحوادثُ غيرُ مضمونةِ، وهيَ منْ شيَم الزمانِ" "اء. وقد اعتتـ الدولـة العباسية في باكورتها بكل مـا يـرتبط بالمـال والأسـواق وتتظـيم الأسـعار " كانـت الثـرطة تجـوب أسـواقها وشـوارعها بـأمر صـاحب لـرب الثــرطة لــرد ع المخــالفين وضـــبط الخطـــرين والمعربـدين، وتطبيـق أحكـام الشـرع فـيمن يخـرج عليـه، أو يتجـاوز حدوده، وكذلك يجوبها رجـال المحتسب لمراقية الأسواق، ومحاسبة كل مخالف أو مستغل أو مطفف، وللتأكد من نظافة وسـلامة ما يقدم للناس والمآكل"ب؛

\section{ثانياً : بغداد رأس المال للخلافة العباسية :} وتُعدّ مدينة بغداد رأس المال للخلافة العباسية، فقد حظيت مدينـة بغداد بموقع محصن، ويعود بناؤه إلىى الخليفـة العباسـي أبـي جعفـر المنصـور ؛ إذ رغب في تأسيس مدينة يأمن فيه على نفسه وعلى جنده بعد الثورات التي قامت عليه وشكلت خطراً عظيماً، وطبيعتها سهلة مفتوحة وتقع بين نهرين
المؤسسة على الأخلاق وعلى رأسها تقدير النعمة؛ لما له من أثر في استقامة النفوس وتهذيبها، وهو

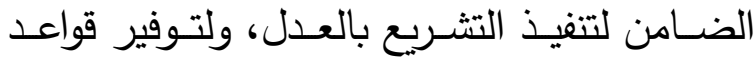
المسـاواة فتحفظ السـادة من مزالق الثـهوة وسطوة السلطة، كما حذّر من الركون إلى الدنيا والتهافت عليها. وهكذا فقد بدأت الوصية بالاستفهام الذي يفيـد إثارة الموصـي لقـيم الحمـد على عطـاء الله والتواضع الذي يزداد بالثكر على النعم ، يقول: "

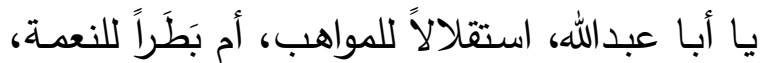
أم قلة علم بموضـع المصيبة؛ كأنك جاهل بمالك وعَلَيْكَ، وهـذا الـذي أنــت فيـهـ عطـاء مـن الله، إن شكرته عليه زادك، وإن عرفت موضـع البلاء فيه

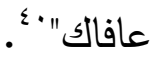
والخليفة المنصور يستغلّ كل لحظة يضرب مثلاً، و ينطلق من لقطات حيـة من الواقع ليصـل إلى تحقيق مبتغــاه، فـالنعم تـدوم بالثـكر ، واصـطناع الرجال يدوم بالاحترام، والنماء يُستجلب بالإحسان وصلة الرحم وإشرالك بني العمومة في النعم، بعيداً عن التباغض؛ فحياة أهل السيادة تطيب بالعدالة وتحقيق الأمـن المـادي، إنّ الخليفـة يقدّم نصـائح مادية ترتبط بالمـال والنفقة والتحذير المتكرر من التبـذير ، وبخاصــة أنّ المـآزق فـي الـدول غيـر مضـمونة، وللمـال دور مهـم في السـيطرة على بطانته، وبسط نفوذه، ويتمثل التوزيع العادل للثروة المالية في توسيع معساش العامـة، وتأمين السكن والمرافق، وفي أرزاق الجند، وتحصـين الثغـور ، وضرورة مواجهة النفقات المتجددة للدولة، كما أن ولن خزينة الدولة يجب أن تمتلئ بالمال؛ فموارد الدولة لايُستهان بها، والخزينـة مظهر من مظـاهر القوة، 
الإنسـانية التي تسكل إعانـة الأفراد، والبعد عن الأنانية التي تعزل السلطة عن الرعية.

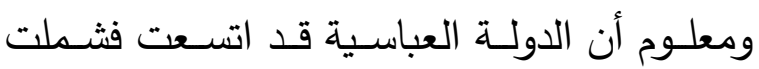
أجناس بشرية مختلفة، امتزجت وانصهرت وشكلت في مجموعها الدولة العباسية القوية في باكورتها.

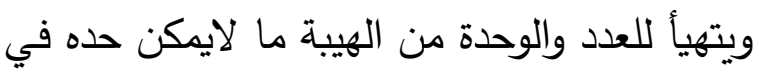

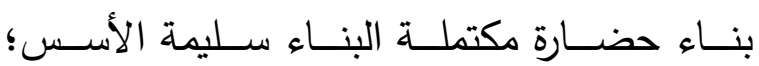
فالأخلاق والوحدة والعدد ترفع السلطة فكراً وواقعاً

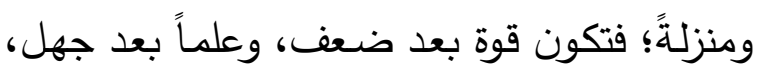

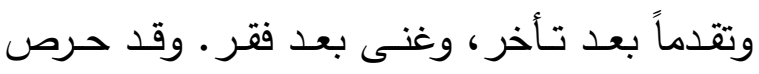

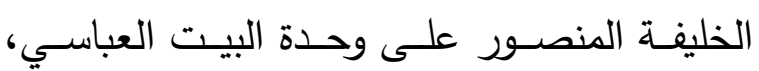
فحضّ ابنه على الإحسان إلى أهل بيته المقربين،

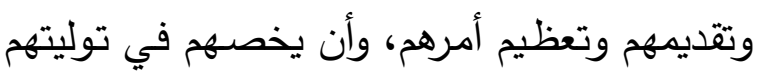

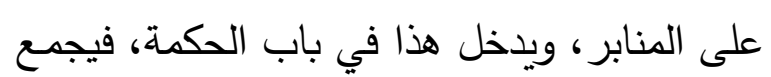

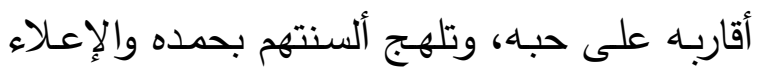

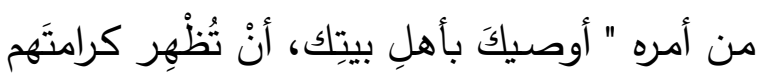

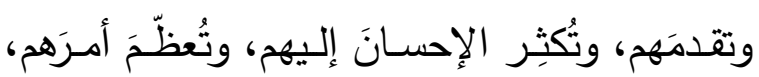

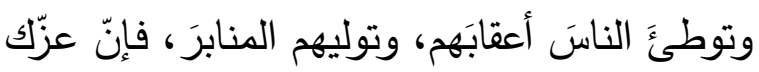
عزهم، وذكرَهم لك". "َّ.

ويُعدّ أهل الدين أداة مهرهـة في توطيد السلطة

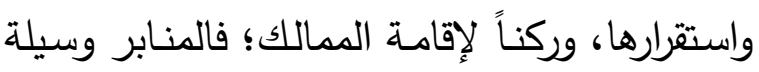
إعلامية لتثبيت أركان الدولة والدفاع عنها:" وأهل

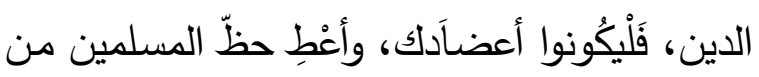

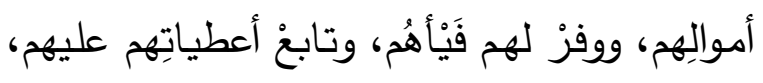

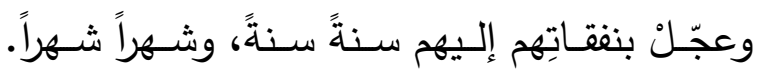

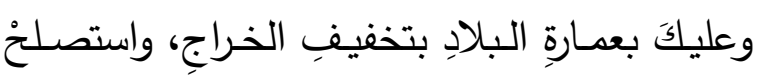

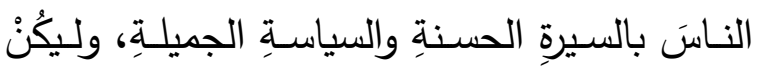

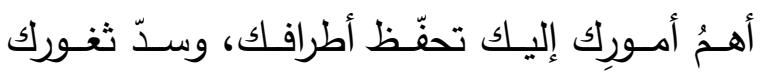

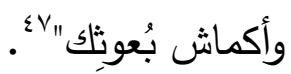

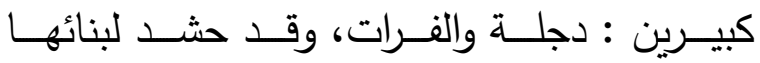
المهندسين والبنـائين والعهـال المهرة، وجعل لهـا أربعة أبواب، وكانت ملتقى للقوافل التجارية فكانت تمتلـئ بالبضـائع والخيرات، وضـرب على ســائر

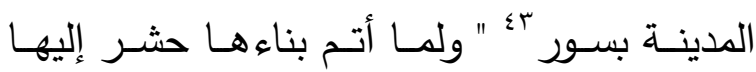
المنصور العلماء من كل بلد، وإقليم، فأمّها أفواجاً،

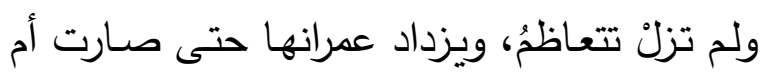
الدنيا ، وسيدة البلاد، ومهد الحضـارة الإسـلامية

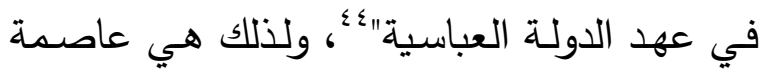
الخلافة العباسية، ولم يكن انتقاء المدينة عشوائياً، فيحذره من تغيير المكان ومن الويلات التي ستجر

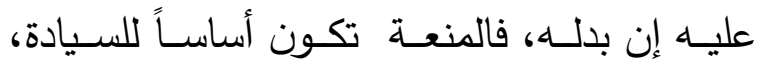
يقول: "وانظُرْ هذه المدينةً، فإياك أن تستبدل بها، فإنها بيتك وعزلك، قد جمعت لك فيها من الأموال، ما إن كسر عليك الخراج عشر سنين، كان عندك فئك

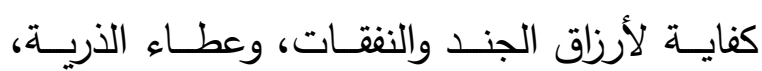
ومصلحة الثغور ، فاحتفظ بها فإنك لا تزال عزيزاً ما دام بيت مالك عامراً..." ؛؛

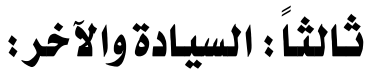
لا تقوم الأمـم والحضــارات إلا بالتعاضـــ والتـرابط وبوجـود أفراد يجمعهم التعاون وتسودهم الألفـة،

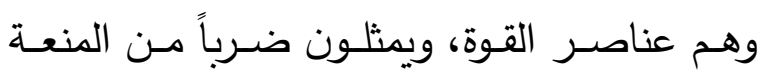
والقدرة على دفع العدوان ، ومن هنا فإن وصـايا الخليفـة تقـوم في مركزيتهـا التي تتكئ عليهـا

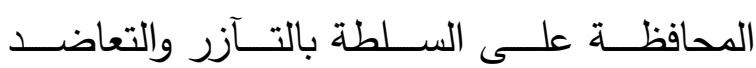

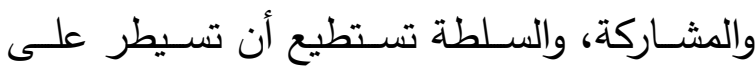
العـدد الكبيـر مـن الرعيـة بحسـن الخلق، والقيم 
العدل، وأولى الناس بالعفو أقدرهم على العقوبة،

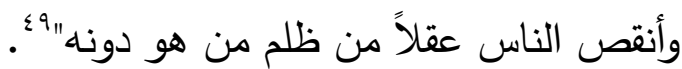
وتكون اليّلطة معرضة للمخاطر أيضاً، ولا بدّ من هن لهن

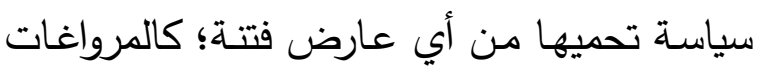
الفكرية. وتقتضي السياسة الذكية العدل في توزيع

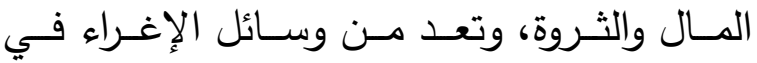

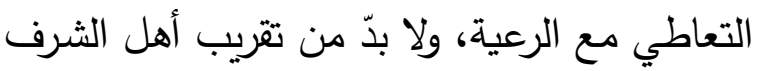

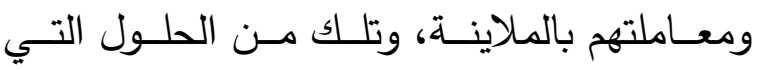
اقتراحها الخليفة في مواجهة ابنه لأي طارئ؛ لذا فهـو يوصـيه بمـن يصـــفيهم لمجالسـته مـن الخاصة: ذوي الثرف والرفعة من النصحاء وأهل

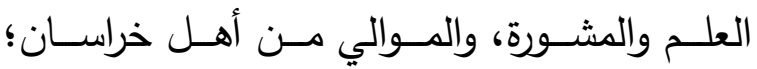

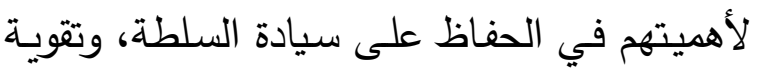
شوكتها، كما دعا الخليفة ابنه إلى تقريب النصحاء من الرعية، وأن يستثر خبرتهم وتجاربهم، فالذكاء في موقف السيادة يتطلب الدهاء، وأن يتعهد من

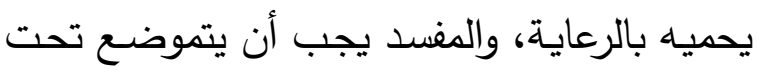
فعل المراقبة والإقصاء فيما بعد، فضرره أكثر من بن نفعه، إن السيادة تتطلب الحيطة واليقظة " وانظز مواليكَ، فأحسنْ إليهم وقرَّهم، فإنهم مادثُك لثدّةٍ

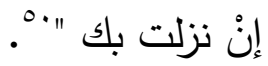

وقد وصف الجاحظ الدولة العباسية في تركيبها

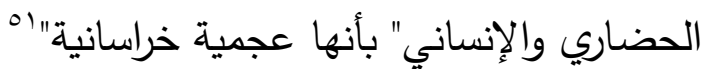
وبيّن الخليفـة المنصـور أن ذهـاب اليّلطة يكون

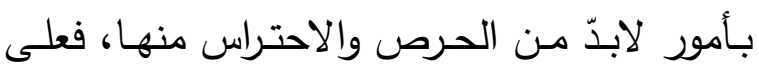

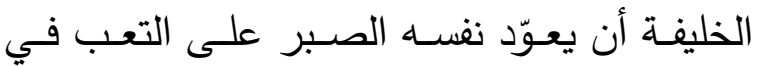
إصلاح من يحيطون به في معاملتهم بين الخوف

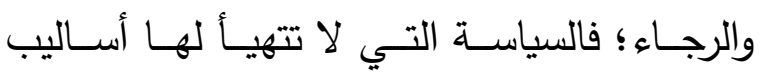
الضبط ، ويغلب عليها الضعف من الخليفة، وفقد
ولا يمكن أن يقوم الحكم إلا بقاعدة جماهيريـة"

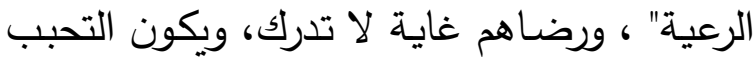

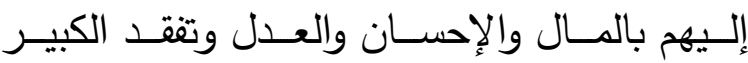
والصغير ، وأن يتخير من بينهم الفاضل في ولاية

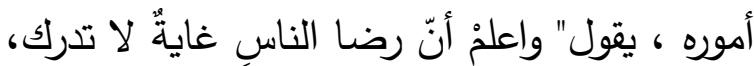
فتحبّب إليهم بالإحسانِ جهدك، وثبّت فيما يَرِدُ من

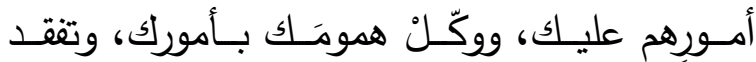
الصغير ، تفقّلك الكبير ..." أ. توحي وصـية أخرى بالتدرج في السياسـة التي يتبعها الخليفة، فأموره تقوم على تعظيم حرمات الله

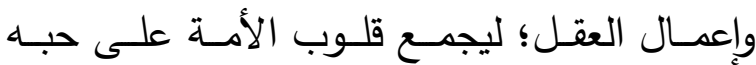
وينعكس بره على الرعية خيراً وصـلاحاً وتسامحاً، وجعل صـفة التقوى أعلى المراتب، وهكذا فـإن الخليفـة يـرى الله في أعمالـه وتصـرفاته : كبيرهـا وصغيرها، فإن كان الخليفة على نصيب كبير من التقوى، تذل لـه رقاب العباد، ويتصدى للظلم، ثم

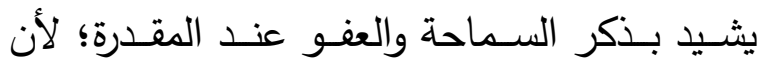
الخليفـة ملجـأ الضـعفاء والفقراء والمسـاكين، وهو لكو يكثف الظلم عن الجميع. إن الخليفة في وصيته يــؤمن بـاختلاف الطبيعـة البثـرية وبنـاء عليهـا تختلف وسـائل التعاملـ و العقـاب، وتكثف هذه

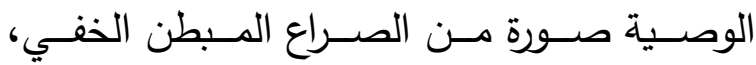
وممارسة الساسة سياسة البطش، وما ينشأ عنها مـن خـوف وقمـع للحريـة، والـــحكم بمصــائر الآخرين، يقول:" يـا بُني لا تُجرم أمراً حتى تُفكر

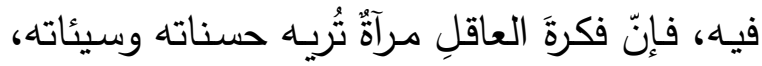
واعلْ أنّ الخليفةََ لا تُصلحه إلا التقوى، والسلطانَ

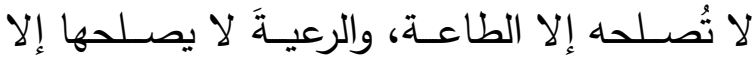


والجند ما استطعت، وإيالك وتأخير عمل اليوم إلى في

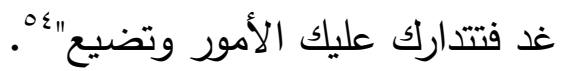
ويبـين لابنــه عناصـر قــوة الخلافــة والســلطة ونصـرتها، ويكمن بتفقد الجيوش بشكل دائم في الليـل والنهـار بعـد الاتكـال على الله، والاستعداد للمعركة للدفاع عن الدين بالسلاح، وتهيئة الجانب المعنوي الذي يعني الكثير للجنود، فقد وظفها هنا إشارة من طرف خفي إلى من يحيط بهم من خطر

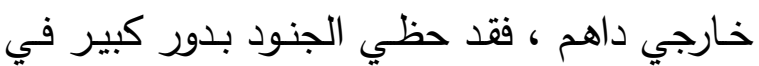

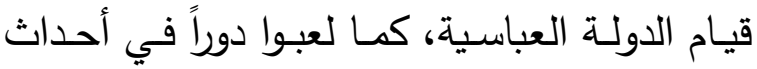
الدولـة، يقـول الخليفـة محذراً، ومستعيناً بـالقرآن: "وأرغب إلى الله عزوجل في الجهاد والمحاماة عن دينه، وإهلالك عدوه بما يفتح الله على المسلمين، ويمكن لهم في الدين، وابذل في ذلك مهجتك ونجدتك ومالك، وتنقد جيوشك ليلك ونهارك ، واصـرف مراكز خيلك، ومـواطن رحلك ، وبـاله فليكن عصمتك وحولك وقوتك ، وعليه فليكن ثقتك واقتدارك وتوكلك، فإنها يكفيك ويغينك وينصرك،

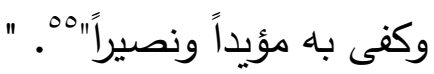
ومن اليقظة والحكمة عدم تأخير الأمور وإحكامها أولاً بأول، وهذا يستدعي وجود عيون يعسون في

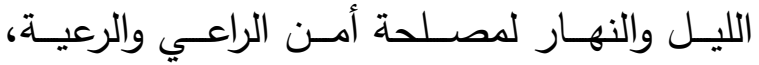
واليقظة الدائمـة تتطلب عدم الركون إلىى الكسل والدعة، فالخلافة مسؤولية عظيمة تتطلب الحذر واليقظة وقلة النوم والبعد عن اللهو . كما لا يتخفى الخليفة_في الوقت نفسـهــعن أعين المحتاجين

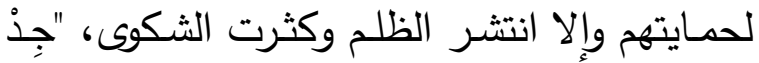
في إحكـامِ الأمـورِ النـازلاتِ لأوقاتِهـا أولاً فـأولاً،

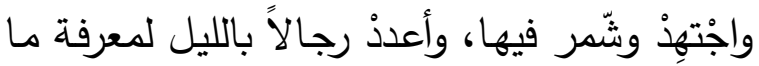

خيار الأعوان؛ أصحاب العقول الراجحة، ستجعل الرعيـة برجالهـا ينقلبـون على السـلطة، وتتحقـق للمنقلبين الغلبة بالإجماعـ ويخسر الحاكم الولاء الــي يحتاجـهـ حتـى يسـتمر وجـوده، والخليفــة المنصور ينتقد من يحيطون بالخليفة من عمال وولاة ووزراء، فهم يستغلون مناصبهم في الإيذاء وتحقيق مآربهم، وتزيين المساؤئ للخليفة :" واعلْ

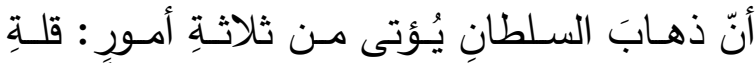
الحزم، وضـعفِ العزم، وفقْدِ صـالح الأعوانِ، وإنِ

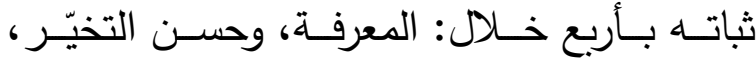

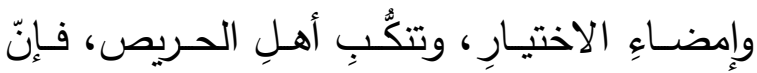
الحـريصَ لايبيعـك باليسـيرِ مـن حظـــهِ وشـره، والوزراء أضرّ الأعداءِ، ومن خانك كذبك، ومن

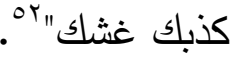
وبمـا أن الدولــة العباسـية شـهدت فتنـاً داخليـة، وكانت علاقتها مع الروم مضطربة، والروم أعداء

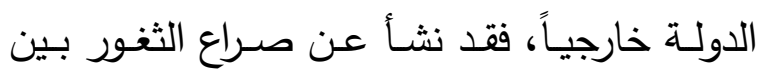
العرب والروم الاهتمام بالجنود المقاتلين ، وشحن الثغور وحماية الحدود، والمعروف أن الصراع بين العرب والروم قديم ولم يظهر أبان الحكم العباسي، فقد " كانت المواقع الدفاعية التي تقع على الحدود بين العرب والروم تسىى الثغور • وفي هذه المواقع كانت تنشأ الأربطة، وهي أماكن تجمع المسلمين الذين نذروا أنغسهم للجهاد بـوازع شخصسي. أمـا

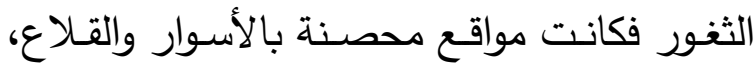

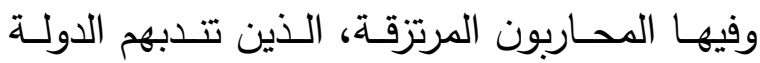

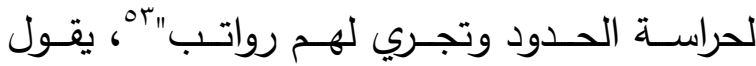

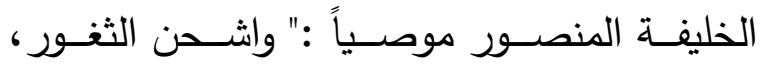
واضبط الأطراف، وامن السبل،...، وأعد الكراع، 
ولكنه الذي يحتال للأمر الذي غشيه حتى لا يقع

\section{ثانياً : السيادةوالتيه الأخلاقية :}

وإذا كـان الهـدف الرئيسـي مـن وصــايا الخلفــاء

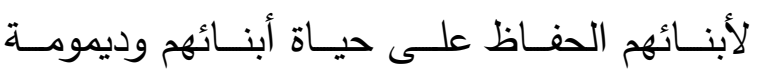

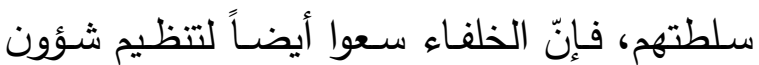
الحيـاة، التـي ترتكز على السـلك القـويم وحسـن

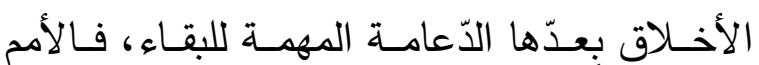
نهضت وتطورت وازدهرت برفيع الأخلاق، وهكذا لـم يـدخر المنصـور في وصـيته شيئًا ليزيـــ ابنـهـ شرفاً ورفعة وذكراً حسناً؛ فوصايا الخليفة المنصور لابنـه تتأسس على محاور مهمـة تقوم على الفعل

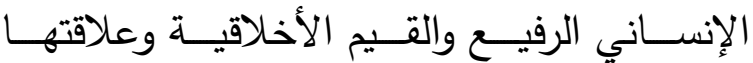
بالديمومـة والثبات فهي تضـبط مطـامع الإنسـان وشــهواته وتكبحهمــا، فالسـيادة لا تعنــي القهـر

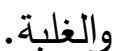

إنّ الخليفــة الأب يســى فــي الوصــايا عــى اختلاف مضامينها أن يجيب على سؤالين اثنيين، وهما : كيف للسلطة أن تحفظ سيادتها؟ وكيف لهـا أن تجعـل الآخـرين يحترمونهـا ويعـزون مسن شأنها؟ إنّ شـؤون الدولـة وسياسـتها تقـوم علـى مفــاهيم مبثوثة في ثقافـة الفكر العربـي السـائد في ذلك الزمن، ولذلك فـانّ مفهوم قبـول الآخر واحترامسه يمثل القيمـة الكبـرى لصـنع عـالم السّـلطة الـذي تتضـخم فيـه الذات( الخليفـة) بعد علو شـأنه مـن الآخر ( قبيلته).

فالسيادة تتكئ على كل خليقة: تعلم العلم والعمل بـه، ومجالســة أهـل العلـم،و تجنـب الثّــــ وذلـك
يكون بالنهار، ورجـالاً بالنهار لمعرفـة مـا يكون بالليـل،.... وباثِـر الأمـورَ بنفِيـك ولا تفجـز ، ولا

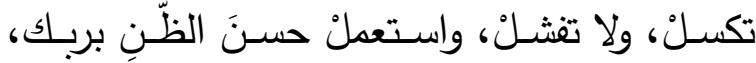
وأسِسئ الظّن بعمالِك وكتابِك، وخُذ نفسك بالتيقّظ، وتققد من يبيـتُ على بابِك، وسـهّلْ إذنك للنـاس، وانظر في أمرِ النََُّّّع إليك، ونفساً غير لاهية، ولا تنم، فإنّ أبالك لـم ينمْ منذ وُلي الخلافةَ، ولا دخل عينه غمض إلا وقلبه مستيقظٌ" إن الوصـايا على اختلافهـا متقاربــة في معانيهـا ومضامينها،" وقد تكون وصسايا الآباء الخلفاء إلى الأبناء( ولاة العهد) متميزة عن غيرها من وصـايا الخلفاء؛ وذلك لمـا فيها من الإعداد والتوجيه إلى الآداب السلطانية في سياسـة الرعيـة. وغيرهـا من الأمور التي تعد (ولي العهد) إلى تولي الحكم"

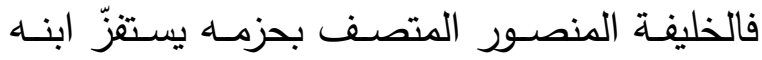
بالاسـتفهام والحـوار لإثارتـهـ ولفـت انتباهـه، فمـن التضييع أن لايدرك ولي العهد ما خوله الله، يقول الخليفة:" كم راية عندك؟ قال: لا أدري، قال: هذا والله التضـيـيع، أنـت لأمـر الخلافـة أشــ تضـيـعاً، ولكن قد جمعت للك ما لا يضرك معه ما ضيعت، فاتق الله فيما خوّلك" "يه . ويُعدُّ الوقوع في الخطأ أمراً طبيعياً، لأنـه يدخل في الطبيعة السلوكية في التصرف، إلا أن الخليفة

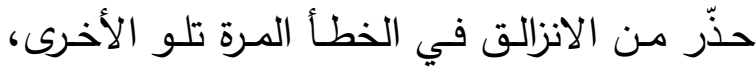
ويكون ذلك بحسن التخطيط، وإعـادة النظر في التصرف بحسَ إيجابي بعيداً عن التخبط لتجنب الوقوع في الخطأ، ويؤدي هذا الأمر للتخفف من السلوكيات السيئة." يـا أبـا عبد الله ، ليس العاقل فئل الذي يحتال للأمر الذي وقع فيه حتى يخرج منـه، 
الأفكار التي تكثف معالم الصراع الإنساني، وما فيها من دفع الظلم عن المظلوم لضـعفه وحمايته، فالسـيادة القويـة تعتتـي بالضـعيف وتحقق الأمـان كل الأفراد، وتحدّ من بطش الظالمين وهيمنتهم، كمـا يـدعو الخليفـة المنصـور إلى إظهار الحكمـة

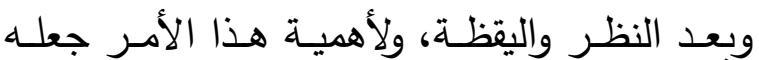
أمانـة في عنقه؛ فالخليفة لم يَسُد قومـه إلا بحفظه لسديد الأخـلاق التي حثّ عليها والده الذي أثبت في وصـاياه أخلاقهـ الرفيعـة أيضـاً، يقول:" وتفقد من يبيت على بابك، وسهل إذنك للناس، وانظر في أمر النزاع إليك، ووكل بهم عينا غير نائمـة، ونفسـا غير لاهيـة، ولا تنم، فإن أباك لم ينم منذ ولـي الخلاقـة، ولا دخـل عينـهـ غــض إلا وقلبـهـ مســتيقظ. هـــه وصـــيتي إليــك، والله خليفتـي عليك" مبك" وممــا أوصــى الخليفــة المنصــور ابنــه، ســلوك الاسـتقامة، ويتمثـل فـي الإصـابة فـي الأقـوال والأعمال ظاهرها وباطنها، وترك المنهيات، وفعل

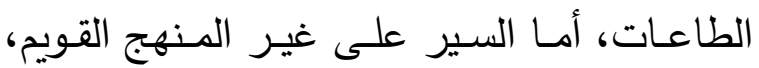
والطغيـان فهمـا مـن الصــور الأخـرى للبعـد عـن الاستقامة ، وقد انعكست هذه الوصـايا على حياة المهدي، وحققت وصـايا والده مبتغاها، فقد : كان المهدي محبباً إلىى الخـاص والعـام، وردّ الأمسوال إلى أصحابها، وأطلق المحبّسين، وأمّن الخائفين، ووصل المعدومين "r آ.

\section{رابعاً: سمات فنية في وصايـا الخليفة العباسي أبي}

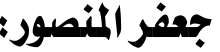

تتكئ الوصـايا على ثلـة من السمات الفنيـة، فهي تتصف بالإيجاز والوضوح والدقة، ورقـة الألفاظ،
باستصلاح الناس بالسيرة العبقة الحسنة، وانصاف النـاس؛ وذلك بـرد المظـالم إلى أصـحابها، والبعد عـن مظــاهر البطـر والكبـر ؛ لأنــه يبعـد قلـوب الرجال، والتواضـع يقرب من الناس، والصفح عن المسئ، وحفظ الجار ، ونصرة الموالي، واصطناع الرجـال ومـن قلل الثكر والحمد فهو داعيـة لكل إساءة و قطيعة . وفي سبيل الحفاظ على الطاعة؛ فإنها يجب على الخليفة أن يقرب من أنس منه طاعة وولاءُ وانتماء بالسـيرة الحســنة وتحسـيين أوضـــاعهم ومراعـاة مصـالحهم العامـة، ويصبر على مـا يحل بـه من خطوب، ويحتمل المشاق، يقول:" واستصلح الناس بالسيرة الحسنة والسياسة الجميلة"، ‘. وتتجلى القـيم الأخلاقيـة في أمسور عـدة تـرتبط بحسن المعشر والإحسان والإنصاف الدائم، فالظلم يحيق بأهله، وتدور دوائره على صـاحبه، كما أن السلوك المهذب من السلطة سيرتدّ عليها احتراماً وتقديراً ورفعةً وجذباً للرعية، ونشاطاً وعملاً، وعلى الراعـي ألا يتســاهل فـي معاملتهـه لرعيتــه بالعـدل والاعتناء بهم، ويتعهدهم بالرعاية والتقدير لما لهما من دور في الانقياد لأوامره، للمحافظه على أمنهـ وحتى يحمـوا ملكـه ويبـلوا أرواحهم في سـبيله، يقول: " ولتصـدق الله نيتك، وتعظم إليـه فاقتكل، وليتسـع إنصـافك، وينبسط عدلك، ويؤمن ظلمك، وواس بين الرعية والاحتكام، واطلب بجهدك رضى

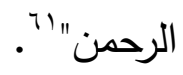
ومـن الأفكـار التكراريـة والمواقف الفكريـة النبيلــة التي يحرص الخليفة على توريثها لابنه، المحافظة على إغاثة الملهوف ومساعدة المحتاج، وهي من 
أسـاءها، ومـا أبغض أحس الحمد إلا استذم، ومـا

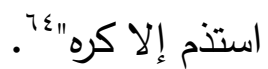

ولنقـل المشـاعر والأحاسـيس، وتعميـق المشـهـ، ومنحسـه دفقـة شـعوريـة، فـإنّ الصـور والتشـييهات والاسـتعارات كانــت حاضـرة، مدــا يحقـق متعــة جمالية في النص، وهذا سهّل وصول مطلبه إلى الموصــى إليـــه بعبـارة مفعدـة بتكثيـف الصــورة الانفعالية، ويزدحم بالدلالات التي تكرس مفهوم

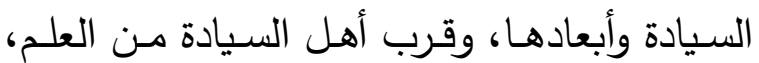
يقول في تأكيد أهمية العلم والحرص عليـه، وفي تحذيره مـن الجهـل:" فـإن حمح بـن شهاب الزهـري قال: الحديث ذكر ولا يحبه إلا ذكور الرجال، ولا

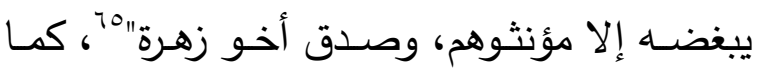
يـربط بين فكرة العاقل والمـرآة التي تعكس أفعال الإنسـان: خيرهـا وشـرها، يقول:" يـا بنـي، لا تبـرم أمراً حتى تفكر فيـه، فـإن فكرة العاقل مـرآة تريـه

$$
\text { حسناته وسيئاته" } 74
$$

كمـا يدعوه للتشـمير عن دينـه والذود عن حمـاه، يقول:"فعليك بالتشـمير لـدينك، والاجتهـاد لنغسـك، فافكك عنقك، وبـادر يومك، واحذر غدك، واتق

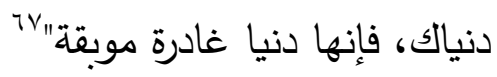
وبمـا أن الوصـايا تصدرر مـن الآبـاء إلى أبنـائهم، فإنها تتصف بصدق العاطفة، فهي تستغل اللحظة لتقديم التجربة؛ لتقود الموصسى إليه إلى السعادة، يقول: "استعن باله على دينك... فكأني بك وقد أوقفت بين يدي الجبار ، وخذلك الأنصار ، وأسلمك الأعوان، وطوقت حجتك، وقلت حيلتك، وأخذت

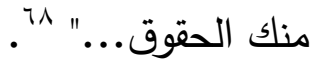

وسـهولة التعـابير ، كمـا اتصـفت مـن جانـب آخـر بالطول والإطناب، إذا أرادت توضيحاً أو شرحاً أو جأ

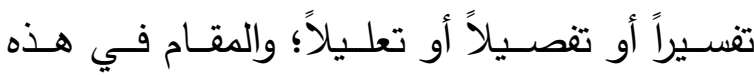
الوصـايا ينبع من خصوصية وضـع السلطة وشدة حرصها على ولي العهد الابن، وبخاصـة لحظات قرب الموصي من منيته. وتراعي الوصـايا الظاهرة العاطفية على اختلافها، وتتطوي على مجموعة من الاستعدادات الخطابية، وتكثف عن حضـور انفعالات خاصـة، ويستعير الموصـي تعـابير القـرب الجسـدي في إيحـاءات العواطـف والأحاسـيس، فتغييــب ذات الموصـي تعني إثبات ذات الموصسى إليه؛ فالموصسي عـادة ما يلجأ إلى الافتتاح باستخدام أسلوب النداء مـع

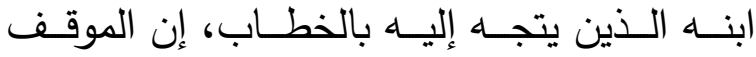
التـأثيري يخضــع عـادة لمنطـق العواطـف، وهـــا الاستهال الدائم بأدوات النداء وذكر الاسم ولفظة (بني) تختزل وسائل الإغراء ولفت الانتباة والإثارة وتحفز استغلال الاستمالة والقبول، ويعد النداء في مثل هذه الوصـايا أسـلوباً رائقـاً يبعـث على بـث الألفــة والحميميـة والمـودة في العلاقـة الإنسـانية، فكانـت الوصـايا في جملتها تحرص على البدايـة بتودد الأب لابنها حتى يلاقي القبول، وتثي تلك المقدمات بمهارة فائقة في مخاطبة عقل الموصى إليه واستلاب أحاسيسه بذكاء، يقول: ( يا بُني، يا

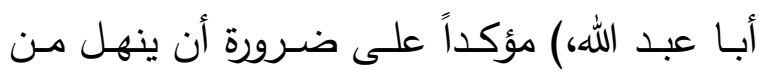

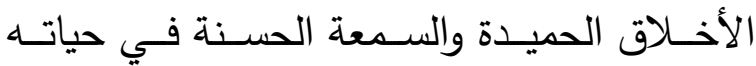
السياسية حتى لا يضـل، يقول :" يـا أبـا عبدالله، من أحبّ الحمد أحسن السيرة، ومن أبغض الحمد 
مهـة في بسط السلطة لنفوذها، فالنهـاء بالعدد،

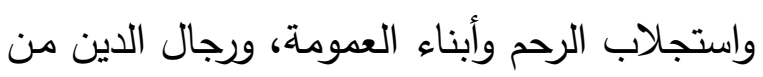

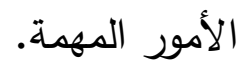
أمـا فنيـاً فقـــ امتـازت الوصـايا بالألفـاظ السـهلة

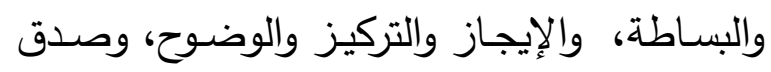
العاطفة؛ وذلك لأنها تصدر من الأب لابنه.

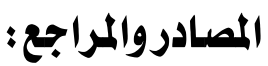

- - إبراهيم أنيس،وآخرون، المعجم الوسيط،، طب،

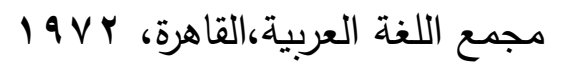

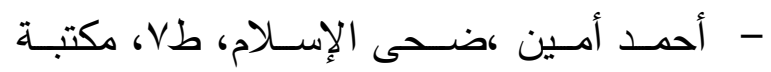

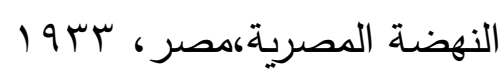

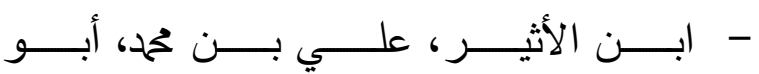
الحسن،(ت • بآهـ الكامـل فـي التـاريخ، صــححه وراجعــه: محمد يوسـف الـــاق، دار الكتب العلمية، بيروت، 19Av - أيمـن الـورداني، حـق الثـعب فـي اسـترداد

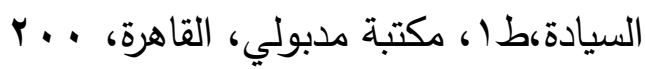

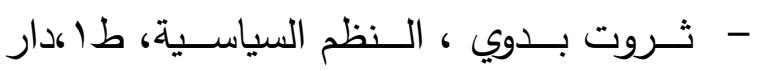

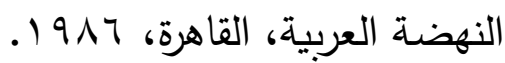

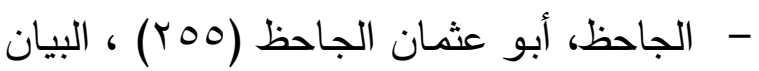
والتبيـين، تحقيـق عبد السـلام هـارون، طلى، مكتبة الخانجي، القاهرة، 1991

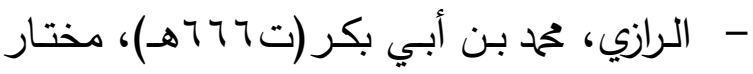
الصحاح،مكتبة لبنان، بيروت، 1911.

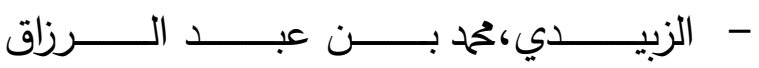

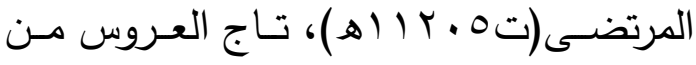
جواهر القاموس،تحقيق: علي شيري، بيروت: دار الفكر للطباعة والنشر، ع 199.
والسلطة تمتاح من معين ثقافتها ومفردات السلطة

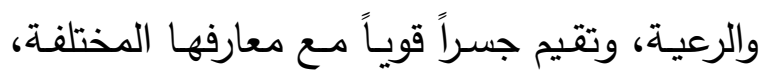
فأفاد الخليفة من الموروثات الفكريـة، حينما ذكّر

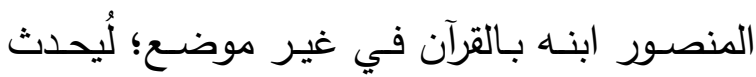

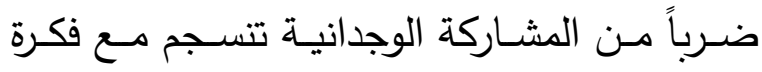

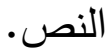

والملاحظ ما يلجأ إليه الموصي من اهتمام واضح بترديد المعنى الواحد في عبارات متعددة ومختلفة؛

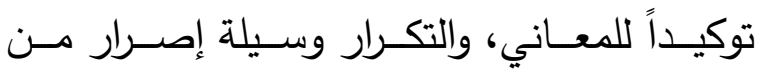

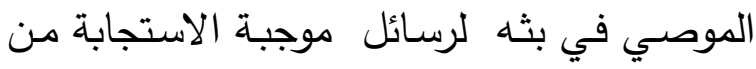

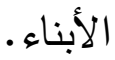

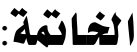

ارتبطـت السـيادة فـي وصـايا الخليفـة العباسـي المنصور بمجموعة من الرؤى التي تضمن ديمومة أهل السلطة وبقائهم في الحكم؛ فهي تتكئ على:

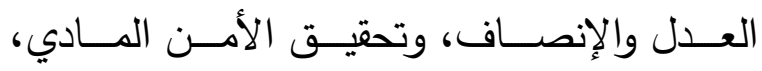

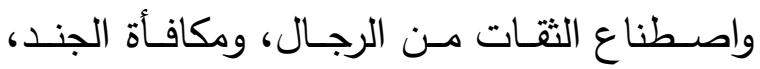
والحرص على شكر النعم، والاستعداد للعدو.

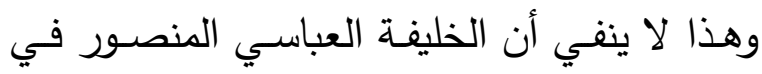

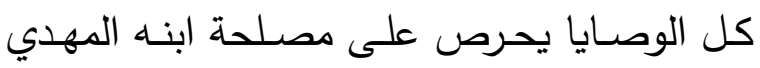

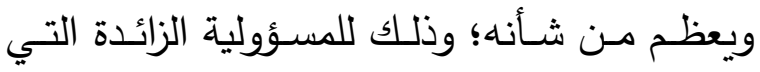

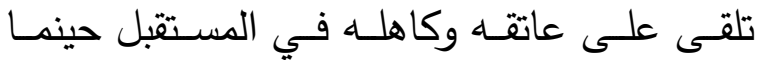

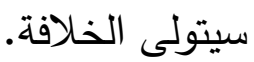
ولعل من أهم الأمور التي نبه الخليفة ابنه عليها

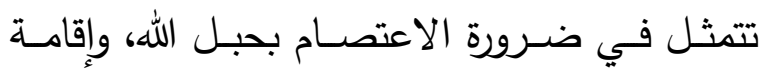
شريعته في ممارسته للسياسـة، فالقيام بتشريعات

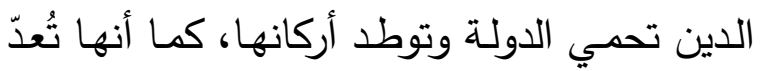

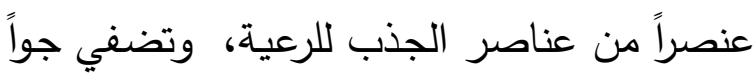
من الزعامة الروحية. ومن ثم كانت الكثرة العددية 
- ابن العماد الحنبلي، عبد الحي بن أحمد بن

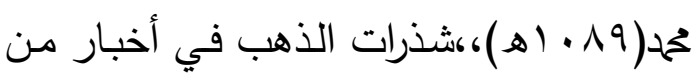
ذهب، القاهرة، · مبا اهـ.

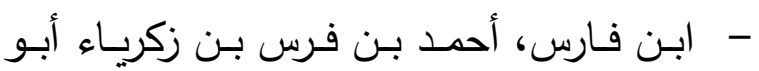

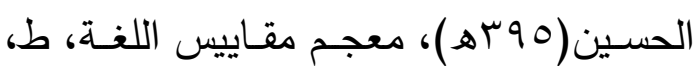

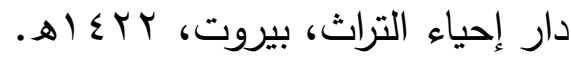

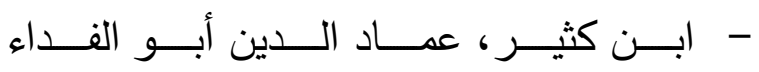

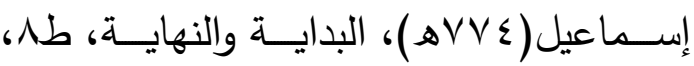
مكتبة المعارف، بيروت، . 99 ـ . - محمد خفــاجي، الحيــاة الأدبيــة فــي العصــر الجاهلي، طا، دار الجيل، بيروت، بو99 إ. - محم الـدليمي، جمهرة وصـايا العـرب( وصـايا العصـر العباسـي، ووصـايا عـرب الأنـدلس)، ج"، منشـورات دار النضــال للطباعـة والنشـر

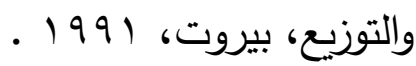
- محمد سـلام، الأدب في عصدر العباسيين( منـذ فئن قيام الدولة حتى نهايـة القرن الثالث)، منشـأة

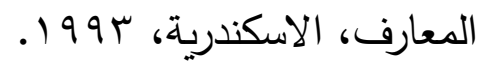
- محمد عطية، الأدب العربي وتاريخه في العصر الابن الجـاهلي، مطبعـة مصـطفى الحلبي، القـاهرة، צr 194. - محمــود الخالـدي، قواعـــ نظـام الحكـم فـي الإســلام، طب، مكتبــة المحتســب، عمــان، بر9 ا المسـعودي، أبـو الحسـن علـي بـن

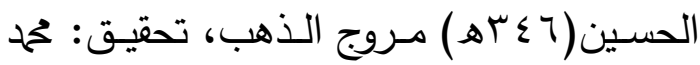

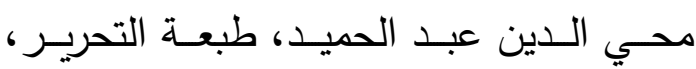
القاهرة، 79 الع 19 مصسطفى أبـو زيـد، فن الحكم في الإسـلام، المكتب المصري الحديث، طا، 1911 19

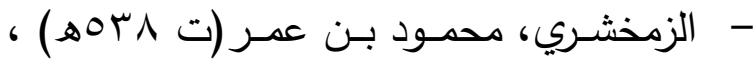
أسـاس البلاغة، تحقيق: حمح باسل ،ط ا، دار الكتب العلمية، بيروت، 991 1.

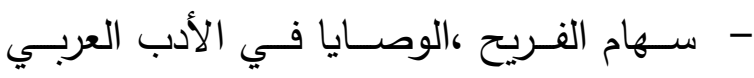
القديم، طا ،الكويـت مكتبـة المعـلا، الكويــ، $.19 \wedge 1$ - ابن شـاكر الكتبي،حمد بن شـاكر بن أحمد(ت ؟ \Vهـ)، فـوات الوفيـات، تحقيـق محمد محيـي الـدين عبدالحميد،مطبعـة السـعادة ، مصسر ، . - الطبري، تحمد جرير أبوجعفر ( • اسهـ)، تاريخ الطبـري: تـاريخ الرسـل والملـوك، تحقيـق: محمد

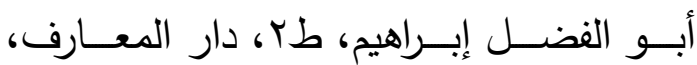
مصر، 1977. - ابـن الطقطقي، محمد بـن علـب بـن طباطبـا أبــوجعفر ، (9. . هـ)، الفخـري فـي الآداب الســلطانية والــدول الإســـلامية، (دط)، دار صادر ، بيروت،(دت). - ابن عبدربهـ، أحمد بـن تحمد أبو عمر شـهاب

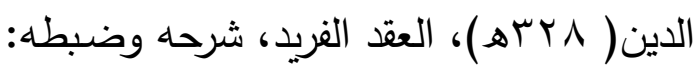
أحمد أمين، أحمد الزين، إبراهيم الأبياري، دار

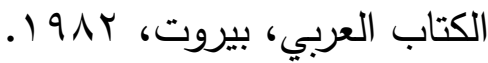

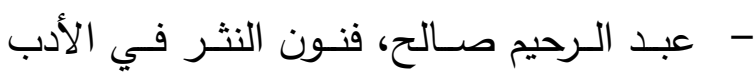

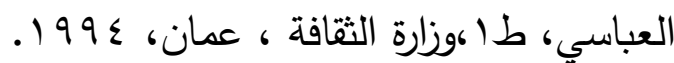

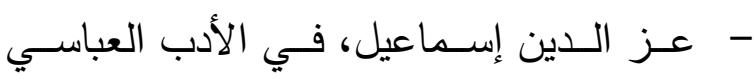

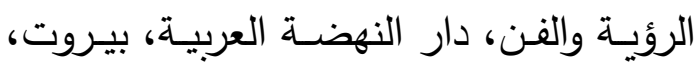
$.19 \vee 0$ عدنان النحوي ، أدب الوصـايا والمـواعظ، دار النحوي، الرياض، 991 1. 
7. مصـطفى أبـو زيـد، فن الحكم في الإسـلام،

طا، المكتـب المصــري الحـديث، مصــر ، •r.

V. أيمـن الـورداني، حـق الثـعب فـي اسـترداد الســيادة، طـا، مكتبـــة مــدبولي، القـــاهرة،

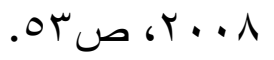

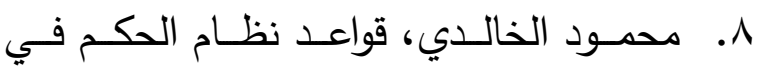
الإســلام، طب، مكتبــة المحتسـبـ، عمــان، (r) 9 9. ابـن فـارس، أحمـد(9 بهـ)، معجم مقـاييس

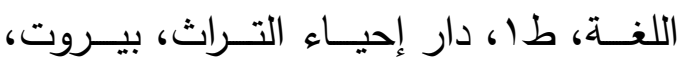
(الم • ـ ـ الزمخشري( بمهــ)،أساس البلاغـة، تحقيق: حمح باسل، طا ، دار الكتب العلمية، بيروت،

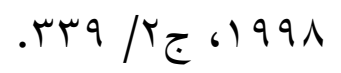

I ا ـابـن منظـور، جمـال الـدين( (1 الهـ)، لسـان

$$
\text { الدين، مادة وصي. }
$$

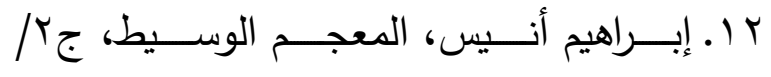

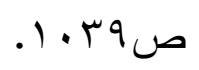

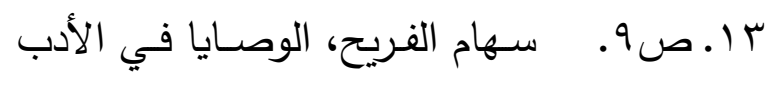
العربي القديم، طا ، مكتبـة المعـلا، الكويـ،

$$
\text { 6) } 911
$$

ع ا ـ حمحد خفـاجي، الحيـاة الأدبيــة فـي العصــر

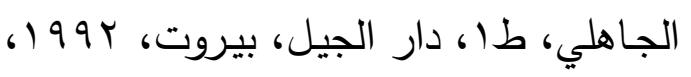

$$
\text { ص صنr }
$$

1 ـ محمد عطيــة، الأدب العربــي وتاريخــه فـي العصر الجـاهلي، مطبعة مصطفى الحلبي،

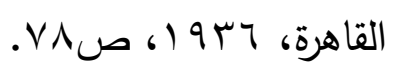

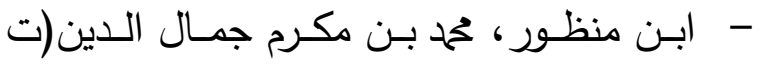

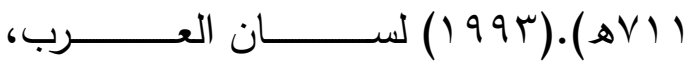
تحقيق:إحســان عبــاس، طس، دار صـــادر ، بيروت، ب9 199 19.

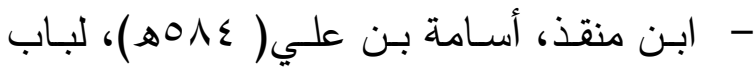
الآداب، تحقيق: أحمد محمد شـاكر ،ط ا، مكتبـة السنة، القاهرة. - - الت. - اليعقوبي، أحمد بن أبي يعقوب( ت ع \& هـ)، تـاريخ اليعقـوبي،(دط) مطبعـة ليـدن، الهنـــ، . NAN

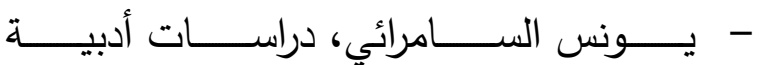
عباسـية،طـ ،دار الثــؤون الثقافيــة العامــة،

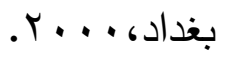
الهموامش ا. الرازي، ححمـ( ד77هـ)، مختار الصحاح، متبة لبنان، بيروت، 919 1، مادة سود.

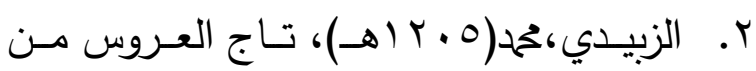
جواهر القاموس،تحقيق:علي شيري، دارالفكر للطباعة والنشر ، بيروت، ع 9 ()، ص بr. r. ابـن منظـور، جمـال الـدين( ( الVهـ)، لسـان العـرب، تحقيـق: إحسـان عبـاس، طب، دار

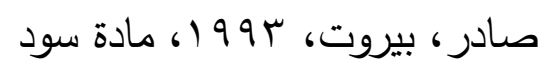
؟. إبـراهيم أنـيس، وآخـرون، المعجـم الوسـيط،

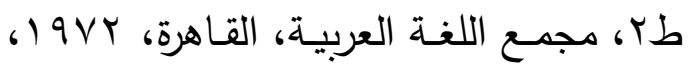
ص. • ه. ــروت بـدوي، الـنظم السياسـية، طـا، دار

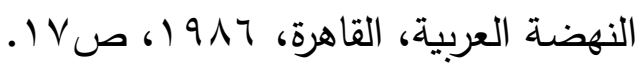




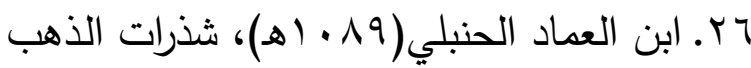

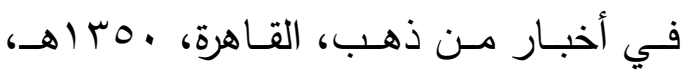
$r T Y / Y$

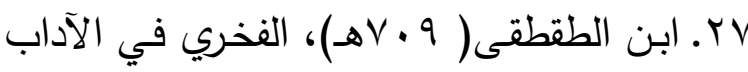
السـلطانية والــدول الإســلامية، (دط)، دار

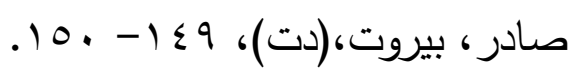

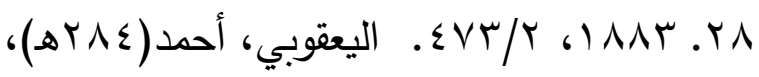

تاريخ اليعقوبي، دط، مطبعة ليدن، الهند،

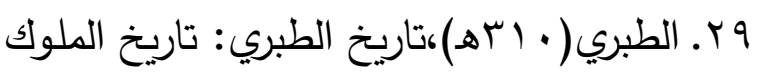
الرسل والملـوك،تح: حمد أبو الفضـل إبراهيم،

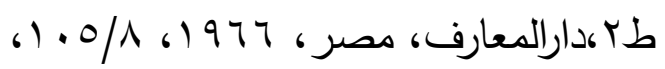
•r. ربه،العقد الفريدهرحه:أحمد آمينهدار الكتاب

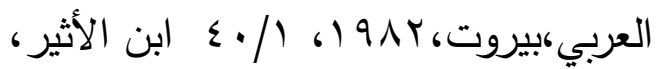

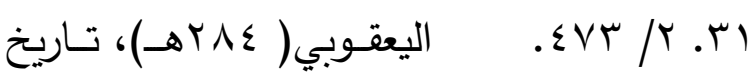
اليعقوبي،

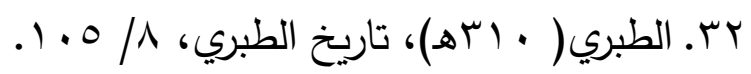

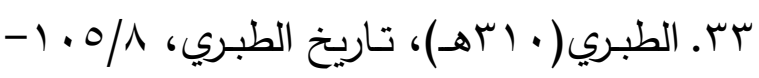

\section{7}

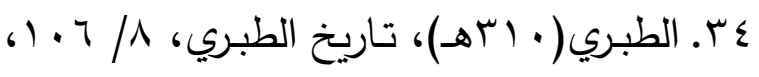

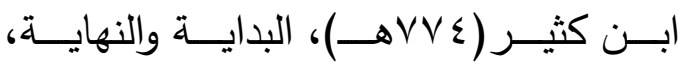

$$
.1 \% T / 1 \text {. }
$$

هr.

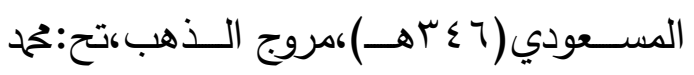

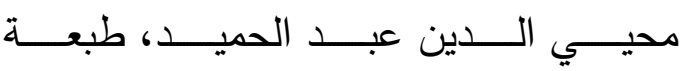

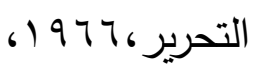

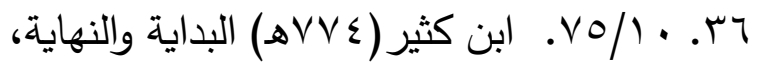

T 1 ـ يونس السامرائي، دراسات أدبية عباسية،ط ب، دار الثؤون الثقافية العامـة، بغداد، . . . ب،

$$
\text { صس }
$$

V I . حمح الدليمي، جمهرة وصـايا العرب، منشورات دار النضــال للطلاعـــة والنشــر والتوزيــعـ،

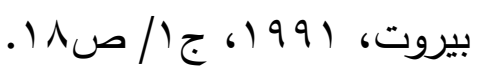

1 ا ـ عبد الـرحيم صـالح، فنـون النثر في الأدب

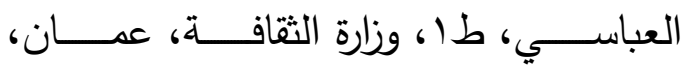

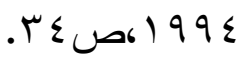

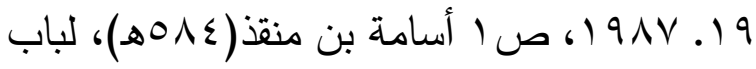
الآداب، تحقيق: أحمد محمد شاكر، طا، مكتبة

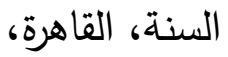
•r. . سهام فريح،الوصايا في الأدب العربي القديم،

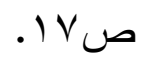

ا r. عدنان النحوي، أدب الوصـايا والمواعظ، دار

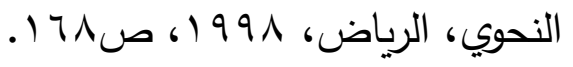

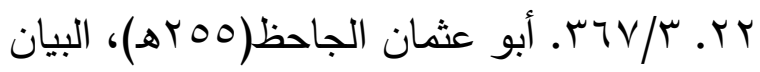

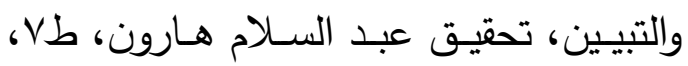
مكتبة الخانجي، القاهرة، 9919

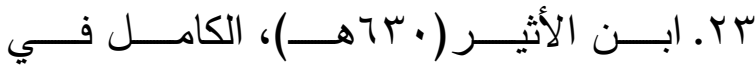
التاريخ،صـحصه وراجعـه: محمد يوسف الدقاق،

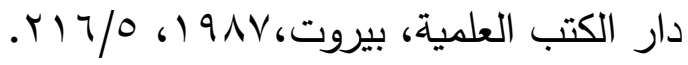

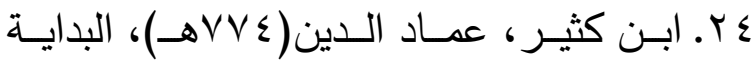
والنهايــة، طه، مكتبــة المعــارف، بيـروت، $.150 / 1.6199$.

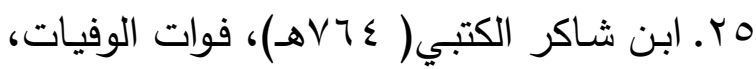
تحقيـق : حمد محيـي الــدين عبــد الحميـد،

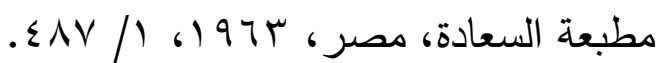


ror. حمح الدليمي، جمهرة وصايا العرب، 9/9 ـ 1. به. عـز الـدين إســاعيل، في الأدب العباسـي الرؤيــــة والفـــن، دار النهضــــــة العربيــــة ،

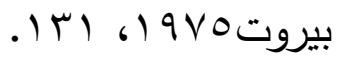

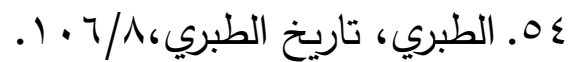

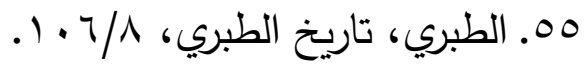

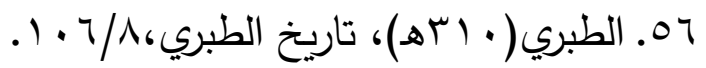
a . aـهام فـريح، الوصــايا فـي الأدب العربـي القديم، 17

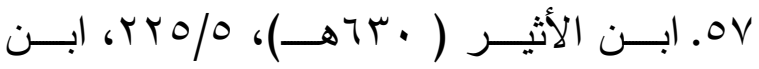

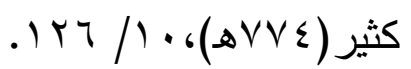

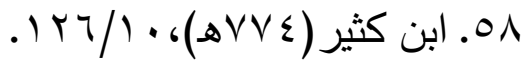

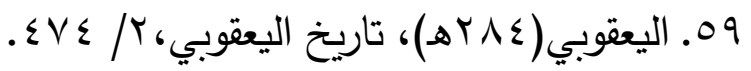

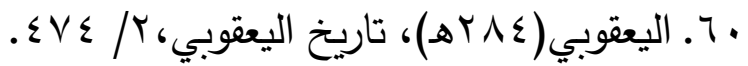

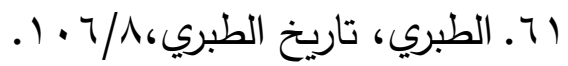

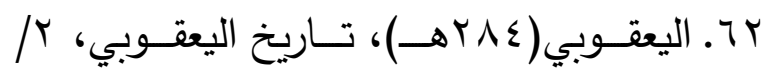
.$\Sigma \vee T$

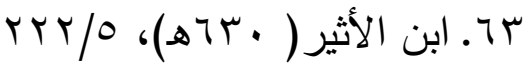

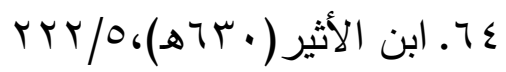

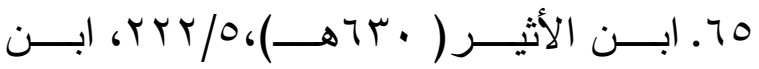

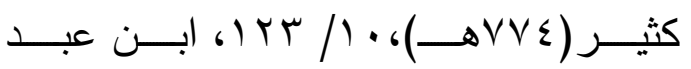

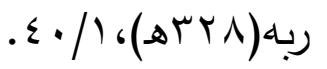

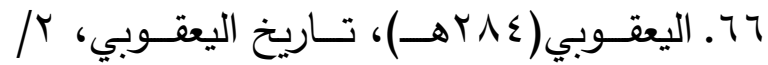
$. \leqslant \vee \leqslant$

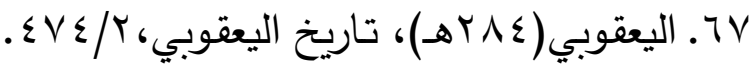

MV محمد سـلام، الأدب في عصر العباسيين( منذ قيام الدولة حتى نهايـة القرن الثالث)، منشأة

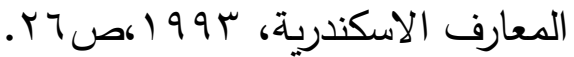

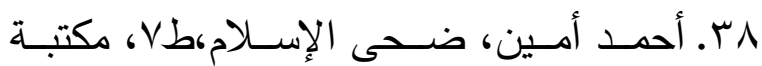
النهضة، القاهرة، ص ه . 1-7 • 1. q ب. ابن الطقطقى،الفخري في الآدب السلطانية، $.17 .-109$

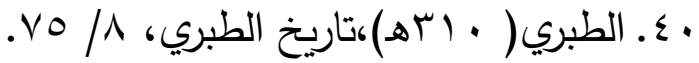

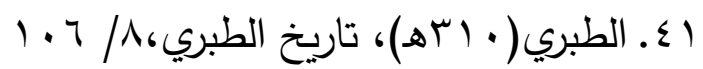

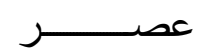

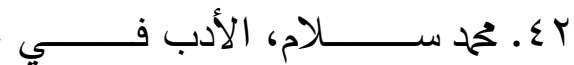
العباسيين،صس

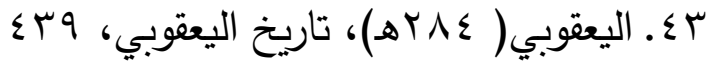
§ء. ابـن الأثيـر (• (r7هـ)، الكامـل في التـاريخ، $177-170 \%$

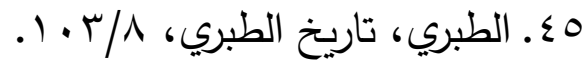

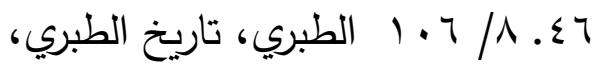

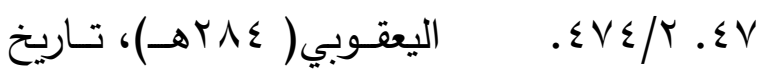
اليعقوبي، ^§. تحمد الـليمي، جمهرة وصـايا العـرب( وصـايا العصـر العباسـي، ووصـايا عـرب الأندلس، $.1 \cdot 1 / v$ 9 ــ ابـن الأثيـر ( • سדهـ)،الكامل فـي التـاريخ، 

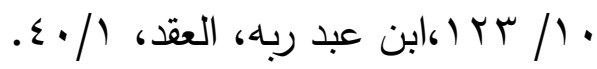

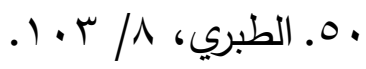

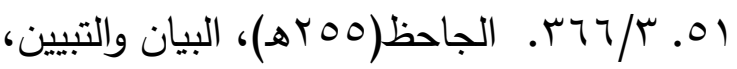

